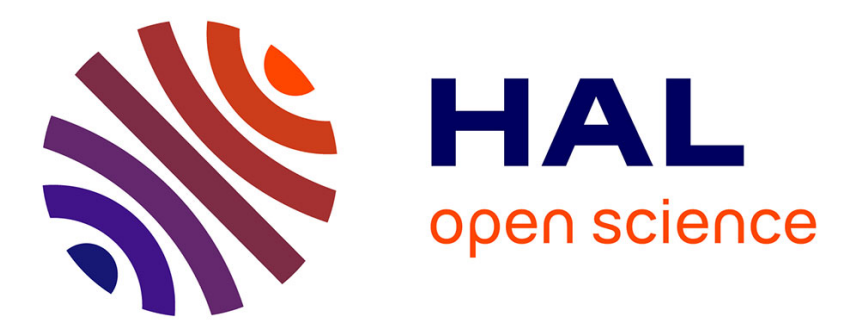

\title{
Selective estrogen-receptor modulators (SERMs) in the cyclopentadienylrhenium tricarbonyl series: Synthesis and biological behaviour
}

Siden Top, A Vessieres, Pascal Pigeon, Mn Rager, M Huche, E Salomon, C Cabestaing, J Vaissermann, G. Jaouen

\section{To cite this version:}

Siden Top, A Vessieres, Pascal Pigeon, Mn Rager, M Huche, et al.. Selective estrogen-receptor modulators (SERMs) in the cyclopentadienylrhenium tricarbonyl series: Synthesis and biological behaviour. ChemBioChem, 2004, 5 (8), pp.1104-1113. 10.1002/cbic.200400067 . hal-01230404

\author{
HAL Id: hal-01230404 \\ https://hal.science/hal-01230404
}

Submitted on 17 May 2021

HAL is a multi-disciplinary open access archive for the deposit and dissemination of scientific research documents, whether they are published or not. The documents may come from teaching and research institutions in France or abroad, or from public or private research centers.
L'archive ouverte pluridisciplinaire HAL, est destinée au dépôt et à la diffusion de documents scientifiques de niveau recherche, publiés ou non, émanant des établissements d'enseignement et de recherche français ou étrangers, des laboratoires publics ou privés. 


\title{
Selective Estrogen- Receptor Modulators (SERMs) in the Cyclopentadienylrhenium Tricarbonyl Series: Synthesis and Biological Behaviour
}

Siden Top, ${ }^{[\mathrm{a}]}$ Anne Vessières,${ }^{[\mathrm{a}]}$ Pascal Pigeon, ${ }^{[\mathrm{a}]}$ Marie- Noëlle Rager, ${ }^{[\mathrm{a}]}$ Michel Huché,${ }^{\mathrm{a}]}$ Emmanuel Salomon, ${ }^{\text {[a] }}$ Claude Cabestaing, ${ }^{\text {[a] }}$ Jacqueline Vaissermann, ${ }^{[b]}$ Gérard Jaouen, ${ }^{* a]}$

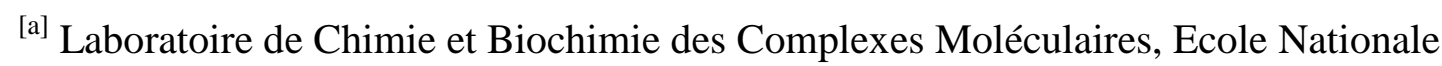
Supérieure de Chimie de Paris, UMR CNRS 7576, 11, rue Pierre et Marie Curie, 75231 Paris Cedex 05 (France), Fax: (+33) 1-43-26-00-61, E-mail: vessieres@ext.jussieu.fr, gerardjaouen@enscp.jussieu.fr

${ }^{[b]}$ Laboratoire de Chimie Inorganique et Matériaux Moléculaires UMR CNRS 7071, Université Pierre et Marie Curie, 75252 Paris Cedex 05 (France)

\begin{abstract}
A series of organometallic antiestrogens based on the $\mathrm{OH}$-tamoxifen (OH-Tam) skeleton and bearing the $\left(\eta^{5}-C_{5} H_{4}\right) \operatorname{Re}^{I}(C O)_{3}$ unit has been prepared by using McMurry coupling for the purpose of studying their biological behaviour. The cyclopentadienylrhenium tricarbonyl moiety is indeed stable in biological media, compact, lipophilic and easy to handle. Furthermore, this study allowed us to select the best candidates for subsequent use as radiopharmaceuticals either for imaging or therapy by using appropriate radionucleides, namely ${ }^{99 m} \mathrm{Tc}$ and ${ }^{188} \mathrm{Re}$. In these molecules the $\beta$-phenyl group of $\mathrm{OH}$-Tam has been replaced by the $\left(\eta^{5}-\mathrm{C}_{5} \mathrm{H}_{4}\right) \mathrm{Re}(\mathrm{CO})_{3}$ moiety, and the length of the dimethylamino side chain $\mathrm{O}\left(\mathrm{CH}_{2}\right)_{n} \mathrm{~N}\left(\mathrm{CH}_{3}\right)_{2}$ was varied $(\mathrm{n}=2,3,4,5$ and 8). The compounds $7 \boldsymbol{a}-7 \boldsymbol{e}$ were obtained as mixtures of their $Z$ and E isomers, which could be separated by semipreparative HPLC. Unlike their ferrocene homologues, the compounds do not isomerise in solution. Structural identification was carried out with NMR spectroscopy by using the HMBC and NOE techniques and was confirmed by the $X$ - ray structural determination of $(E)-7 \boldsymbol{a}(\mathrm{n}=2)$. These molecules were more lipophilic than $\mathrm{OH}$-Tam $\left(\log \mathrm{P}_{o / w}=4.5-6.3\right)$ and they were all
\end{abstract}


reasonably well recognized by the two forms of the estrogen receptor (ER $\alpha$ and ER $\beta$ ). For example, $(\mathrm{Z})-7 \boldsymbol{b}(\mathrm{n}=3)$ has high relative binding affinity $(R B A)$ values of $31 \%$ for ER $\alpha$ and $16.8 \%$ for ERß. The antiproliferative effects of two pairs of isomers, $(Z)-$ and $(E)-7 \boldsymbol{b}(\mathrm{n}=3)$ and $(Z)-$ and $(E)-7 \boldsymbol{d}(\mathrm{n}=5)$, were studied at a molarity of $1 \mu M$ on two breast-cancer cell

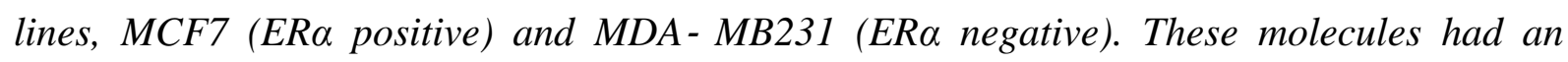
antiproliferative effect on MCF7 cells slightly higher than that of $\mathrm{OH}$ - Tam and no effect on MDA-MB231 cells. Thus, the antiproliferative effect observed on the MCF7 cells seemed essentially to be linked to an antiestrogenic effect. Molecular modelling studies have allowed us to rationalise these effects and select the best compounds for future development of a radioactive series.

\section{Introduction}

Despite the widespread occurrence of breast cancer in the western world, where one woman in eight will be affected during her lifetime, breast cancer therapy still suffers from serious deficiencies in available strategies for treatment, and mortality remains close to $30 \% .{ }^{[1-3]}$ The personal and social costs involved make it imperative to seek novel approaches to treat the disease. Until recently, two types of breast tumours were generally recognised: those defined as hormone- dependent, in which the estrogen receptor is found to be present $(\operatorname{ER}(+))$, and which make up two- thirds of tumours; and those considered hormone- independent, in which the estrogen receptor is not detected $(\operatorname{ER}(-))$, which account for the remaining third of cases. For ER(+) tumours, adjuvant treatment normally includes administration of an antiestrogen. In most cases, this will be tamoxifen ( $1 \mathbf{a}$, Tam), the most widely used of the antiestrogens and the prodrug of hydroxytamoxifen-the active molecule. However, it is known that one- third of the tumours will respond to hormone therapy over a long period, another third will only be responsive for a short period (3-6 months), and the final third will not respond at all. It is thus evident that there is a need for new selective estrogen- receptor modulators (SERMs) with a different, and possibly broader, therapeutic range. ${ }^{[4,5]}$

Our understanding of the mechanism of action of estrogens and antiestrogens has recently undergone substantial evolution owing to a number of major advances in endocrinology research, such as i) the discovery of the existence of a second estrogen receptor, so that two differentiated receptors, ER $\alpha$ and $\mathrm{ER} \beta$, must now be considered; ii) the X-ray structural 
determination of the ligand binding domain (LBD) of the two receptors ER $\alpha$ and ER $\beta$ with estrogens and antiestrogens docked in the binding site ${ }^{[6-10]}$ and iii) the discovery of two different mechanisms of gene activation at the DNA level: either via an estrogen response element (ERE), in which the receptor bound to its bioligand dimerises and interacts with DNA, or via an activated protein (AP1), in which the monomeric receptor bound to its bioligand interacts with two proteins (Jun and Fos) to form a complex that binds to DNA. ${ }^{[11,12]}$ In the latter case, the receptor does not bind directly to DNA. Furthermore, the recruitment of coactivators depends on the type of mechanism and the nature of the target cells. This important multifaceted breakthrough adds a degree of complexity to the problem, but conversely also provides the first precise molecular and supramolecular view of the situation, and allows a reasoned chemical approach to be attempted.

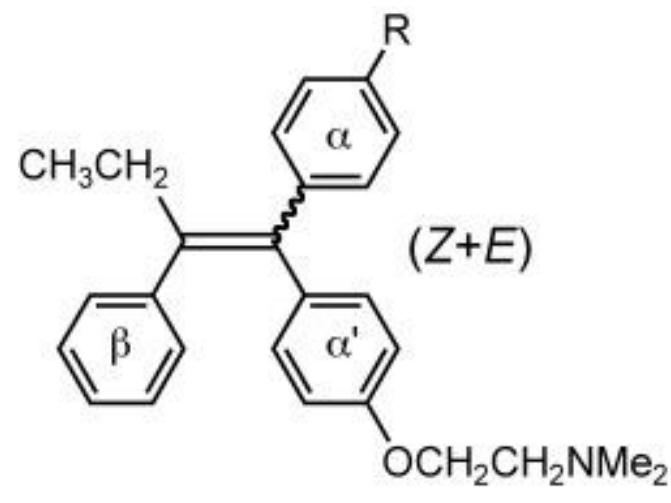

$1 \mathrm{a}: \mathrm{R}=\mathrm{H}(\mathrm{Tam})$

1 b : $\mathrm{R}=\mathrm{OH}(\mathrm{OH}-\mathrm{Tam})$

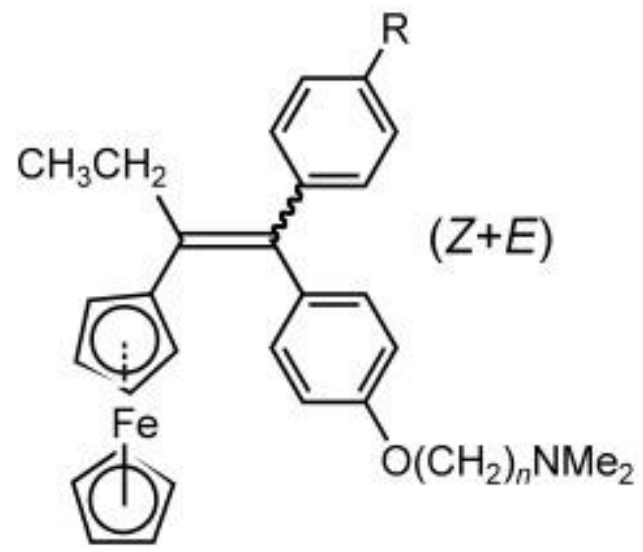

$2 \mathrm{a}: \mathrm{R}=\mathrm{H} ; n=2$ (Ferrocifen)

$2 \mathbf{b}: \mathbf{R}=\mathrm{OH} ; n=3(\mathrm{OH}[3]-F e r r o c i f e n)$

$2 \mathrm{c}: \mathrm{R}=\mathrm{OH} ; n=4(\mathrm{OH}[4]-$ Ferrocifen $)$

It should first be borne in mind that, following the recent breakthroughs, most tumours classed ER(-) as a result of their lack of ER $\alpha$ have now been shown to contain the second form of the receptor, $(\mathrm{ER} \beta)$, albeit in lower quantities, ${ }^{[13]}$ and it is possible that tamoxifen- resistant tumours may respond via ER $\beta$, although a precise role for this receptor has not yet been elucidated despite recent advances. ${ }^{[14-16]}$

Since breast tumours are usually heterogeneous and tend to consist of cohorts of both hormone- dependent and hormone- independent cells, finding a single SERM that can resolve the problem is clearly going to be very difficult. Other functionalities need to be added to the SERM in the hope of generating different effects. Accordingly, we decided to 
use the "gold- standard" SERM, tamoxifen, as the vector which could be targeted to the receptor binding site, and to add a functional or potentially functional group to tamoxifen, in this case an organometallic function, that might lead to an increased range of applications. In this way we were able to show that in the ferrocifen series (Chart 1), complexes such as 2 $\mathbf{b}$ and $\mathbf{2} \mathbf{c}$ are both antiestrogenic, owing to their conformational effect on ER $\alpha$, and cytotoxic, perhaps via ER $\beta$, probably as a result of oxidation of the $\mathrm{Fe}^{\mathrm{II}}$ group of the ferrocene. ${ }^{[17]}$ This new approach produces an antiproliferative effect on breast cancer cell lines, whether classed as hormone- dependent (MCF7) or as hormone- independent (MDA- MB231), although the latter in fact contains ER $\beta .{ }^{[18]}$ This increased susceptibility of $\mathbf{2} \mathbf{b}$ and $\mathbf{2} \mathbf{c}$ to oxidation may generate a cytotoxic effect at molarities compatible with therapeutic use $\mathrm{e}^{[17]}$ and promote apoptosis phenomena. ${ }^{[19]}$ In this context, it was interesting to explore the effect of attaching other organometallic moieties to a nanovector based on a tamoxifen skeleton. The $\mathrm{CpRe}(\mathrm{CO})_{3}$ group appeared particularly appropriate for this approach, since it is lipophilic, robust, and small enough in size such that its substitution for the $\beta$ - phenyl of $\mathrm{OH}$ - Tam, the active metabolite of tamoxifen, would not be expected to unduly inhibit the modified SERMs' recognition for their specific receptors. Furthermore, in the group VII series, ${ }^{99 \mathrm{~m}} \mathrm{Tc}$ is a $\gamma$ emitter, while ${ }^{188} \mathrm{Re}$, a radionucleide of $\mathrm{Re}$, is a $90 \% \beta$ emitter and a $10 \% \gamma$ emitter. Therefore, incorporation of these elements should allow the future development of novel organometallic radiopharmaceuticals that can be used in both therapy and imaging. ${ }^{[20-23]}$

In this work, we present the synthesis and characterisation of organometallic SERMs of $\mathrm{CpRe}(\mathrm{CO})_{3}$ derived from $\mathrm{OH}-\mathrm{Tam}$. We have also included a set of biological tests designed to establish the potential interest of these molecules as targets for a future radiopharmaceutical approach, as well as a molecular modelling study to rationalise the observed effects.

\section{Results}

\section{Synthesis and characterisation}

Two guiding ideas lie behind the preparation of the products shown in Scheme 1. Firstly, the metallic element $\mathrm{Re}$ is incorporated into the framework of the $\mathrm{OH}-$ Tam skeleton $(\mathbf{1} \mathbf{b})$ in the form of $\left(\eta^{5}-\mathrm{C}_{5} \mathrm{H}_{5}\right) \mathrm{Re}^{\mathrm{I}}(\mathrm{CO})_{3}$, a robust, compact and nonbulky organometallic moiety which is not susceptible to oxidation. Previous studies have in fact illustrated the interest of the organometallic approach via the chelate route (e.g. $\mathrm{N}_{2} \mathrm{~S}_{2}$ and with $\mathrm{Re}^{\mathrm{V}}$ ), leading to charged 
and bulky species that are unstable in aqueous solution and mask the recognition factors of OH- Tam for the estrogen receptor. ${ }^{[24-26]}$

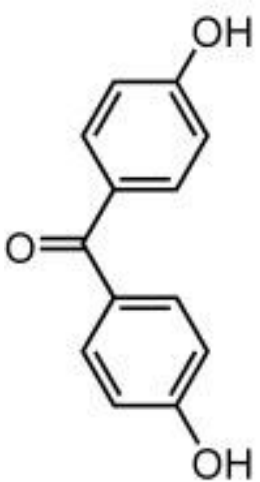

3

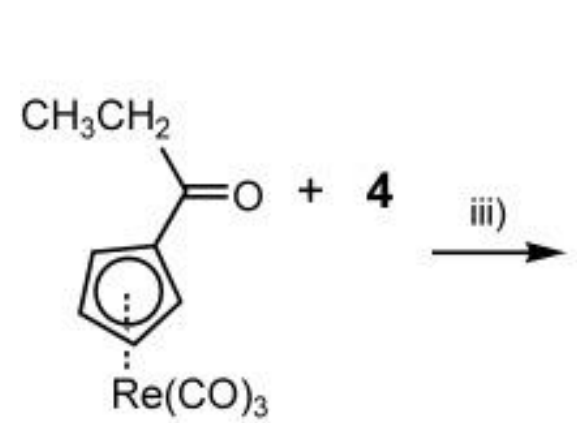

5

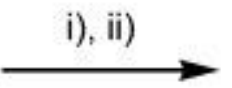

a: $n=2, X=B r$

b: $n=3, \mathrm{X}=\mathrm{Br}$

c: $n=4, X=B r$

d: $n=5, X=\mathrm{Br}$

e: $n=8, X=C l$

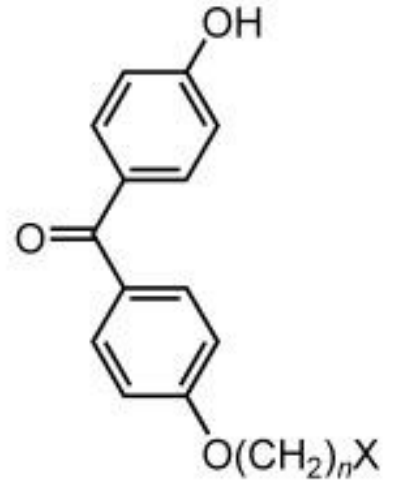

$4 a-e$

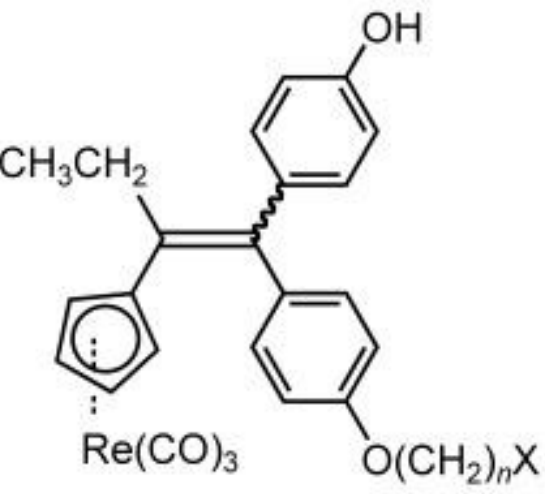

6a-e $(Z+E)$

iv)

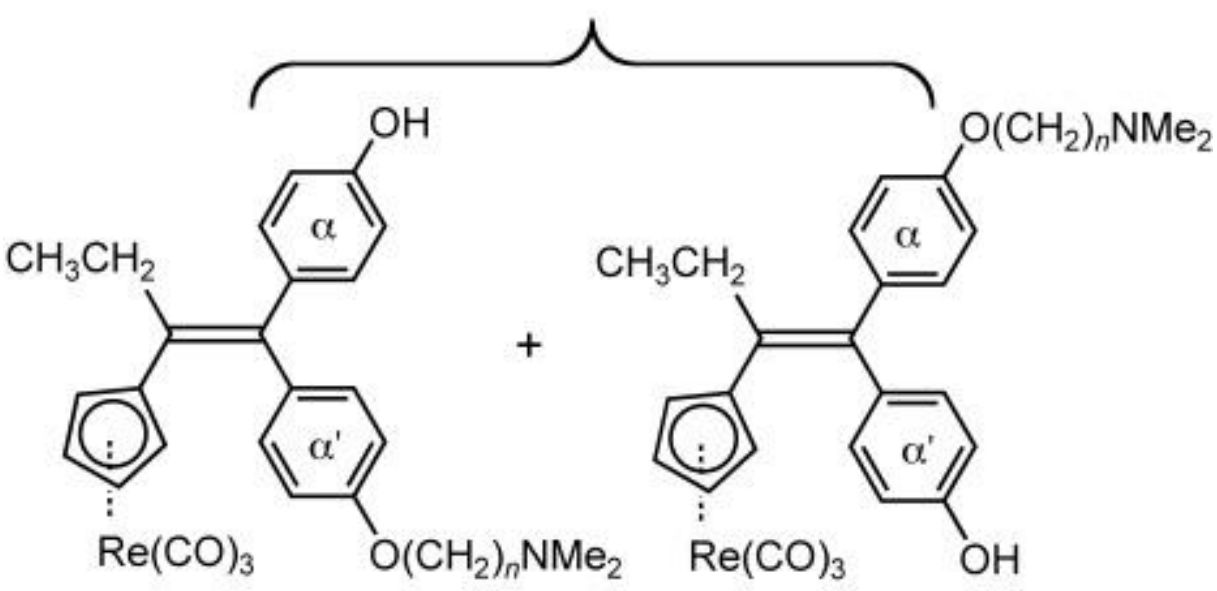

7a-e $(Z)$

7a-e $(E)$ 
Scheme 1 Synthesis of the rhenium derivatives of $\mathrm{OH}-\mathrm{Tam}(7 \boldsymbol{a}-\boldsymbol{e} ; \mathrm{n}=2,3,5$ and 8) by McMurry cross- coupling: i) $\mathrm{KH}, \mathrm{THF}$; ii) $\mathrm{X}\left(\mathrm{CH}_{2}\right)_{n} \mathrm{X}$, THF/DMF; iii) $\mathrm{TiCl} / \mathrm{Zn}$, reflux; iv) $\mathrm{HNMe}_{2} / \mathrm{MeOH}, 60^{\circ} \mathrm{C}$, autoclave. The $Z$ and $E$ isomers are separated by semipreparative HPLC.

In the ferrocifen series, the length of the basic carbon chain proved to be a major factor in the development of antiproliferative activity on breast cancer cell lines. ${ }^{[17]}$ For this reason we varied the length of the carbon chain in our syntheses from $n=2$ to $n=8$, so as to cover a wide range of products. We note that a preliminary study with $n=4$ has already given us a good first approach to the problem. ${ }^{[27]}$

The McMurry coupling reaction arguably remains the method of choice for preparation of alkene derivatives. ${ }^{[28]}$ There are two ways of accessing the desired compounds: the first strategy is to carry out the coupling reaction between propionylcyclopentadienylrhenium tricarbonyl with dihydroxybenzophenone, and to attach the aminoalkyl chain in the last step; the second approach is to attach the aminoalkyl chain onto the dihydroxybenzophenone before carrying out the coupling reaction. Bearing in mind that rhenium is an expensive metal, and that the reaction to attach the aminoalkyl chain is not a high- yielding process as a result of the formation of secondary dialkylated products, it appears preferable to use the second method. However, the coupling reaction with dihydroxybenzophenone bearing the aminated chain does not give good yields because of the insolubility of the ketone, probably as a result of the formation of a zwitterion. To avoid this difficulty, we used a halogenated chain instead of the aminoalkyl chain, and converted the halogenated function to a dimethylamino moiety in the final stage of the synthesis (Scheme 1).

In the first step, 4,4'- dihydroxybenzophenone (3) was monoalkylated with the selected halogenoalkyl chain by using the corresponding dihalide and the monopotassium salt of $\mathbf{3}$ (prepared by the action of potassium hydroxide). McMurry coupling of the corresponding ketone $4 \mathbf{a}-\mathbf{e}$ with ketone 5 gave the alkenes $6 \mathbf{a}-\mathbf{e}$ in good yield ( $>60 \%)$. These alkenes were converted to amines $7 \mathbf{a}-\mathbf{e}$ in an autoclave by treatment with dimethylamine in methanol at $60{ }^{\circ} \mathrm{C}$. Heating at a higher temperature $\left(120^{\circ} \mathrm{C}\right)$ led to unidentified aminated by- products which lowered the yield and were difficult to separate. For $\mathbf{6} \mathbf{a}-\mathbf{d}$, the bromated compounds were synthesised, and heating at $60^{\circ} \mathrm{C}$ for $24 \mathrm{~h}$ was sufficient to obtain the amines $7 \mathbf{a}-\mathbf{d}$. For $6 \mathbf{e}$, the selected halogen is chlorine, and the reaction is much slower, requiring 3 days at $60{ }^{\circ} \mathrm{C}$. 
The McMurry coupling reaction gave a mixture of $Z$ and $E$ isomers with a slight excess of the latter. Unlike the ferrocifens, which interconvert rapidly between the geometric $Z$ and $E$ isomers in solution, particularly in chloroform, ${ }^{[17]}$ none of the rhenium complexes synthesised here showed this tendency to isomerise. This justified the separation of the isomers by HPLC with a reversed- phase preparatory column. By using a mixture of phosphate buffer $(\mathrm{pH} 7)$ and methanol of varied composition according to the isomer pairs, the less lipophilic $Z$ isomer eluted first from the column. Identification of the $Z$ or $E$ configuration of the isomers was carried out by NMR spectroscopy and confirmed by an X- ray structural determination of $(E)-7 \mathbf{a}$. The HMBC technique was used on the $(E)-\mathbf{7} \mathbf{b}$ and $(E)-\mathbf{7} \mathbf{c}$ isomers to permit definite assignments of the protons and carbons. The NOE technique revealed a through- space interaction between the protons of the cyclopentadienyl ring and the aromatic protons of the hydroxyl- bearing $\alpha^{\prime}$ ring on the one hand, and an interaction between the protons of the ethyl group and those of the aminoalkyl- bearing $\alpha$ ring on the other. The existence of these effects is clear proof of the $E$ configuration of these two isomers. This identification is borne out by the $\mathrm{X}$ - ray structural determination of $(E)-7 \mathbf{a}$.

\section{Structure of $(E)-7$ a}

Crystallization of $(E)$ - 7 a from $\mathrm{CH}_{2} \mathrm{Cl}_{2}$ /hexane produced colourless crystals which were suitable for an $\mathrm{X}$ - ray structural determination. $(E)$ - $\mathbf{7}$ a crystallizes in the monoclinic space group P2/a. Crystallographic data are collected in Table 1. A representation of the molecular structure of $(E)-\mathbf{7} \mathbf{a}$ is shown in Figure 1. 


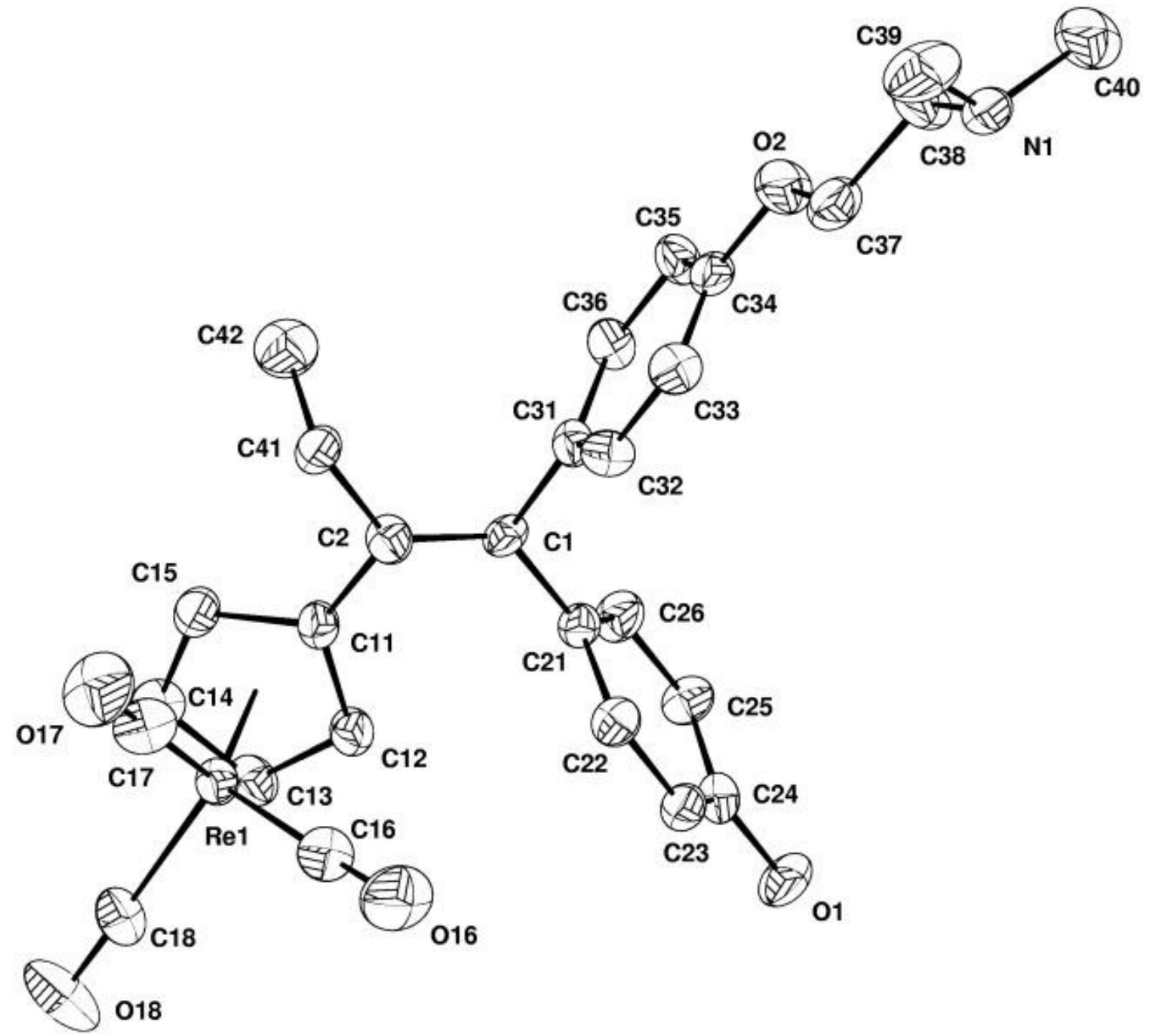

Figure 1 View of the molecular structure of (E)- 7 a showing the atom numbering. Selected bond lengths [Å] and angles $\left[{ }^{\circ}\right]$ : $C(1)-C(2), 1.33(1) ; C(1)-C(21), 1.47(1)$; $C(1)-C(31), 1.47(1) ; C(2)-C(11), 1.48(1)$; $C(11)-$ $C(12), 1.43(1) ; \operatorname{Re}(1)-C(11), 2.33(1) ; \operatorname{Re}(1)-C(16), 1.89(1) ; C(16)-O(16), 1.12(1) ; C(2)-C(1)-C(21)$, $123.5^{\circ}(9)$; $C(2)-C(1)-C(31), 123.1^{\circ}(8) ; C(1)-C(2)-C(11), 124.4^{\circ}(9) ; C(1)-C(2)-C(41), 120.7^{\circ}(9)$.

Table 1. Summary of crystallographic data for (E)- $7 \boldsymbol{a}$.

\begin{tabular}{ll}
\hline Parameter & Value \\
\hline Formula & $\mathrm{C}_{28} \mathrm{H}_{28} \mathrm{NO}_{5} \mathrm{Re}$ \\
$M_{\mathrm{r}}$ & 644.7 \\
\hline
\end{tabular}




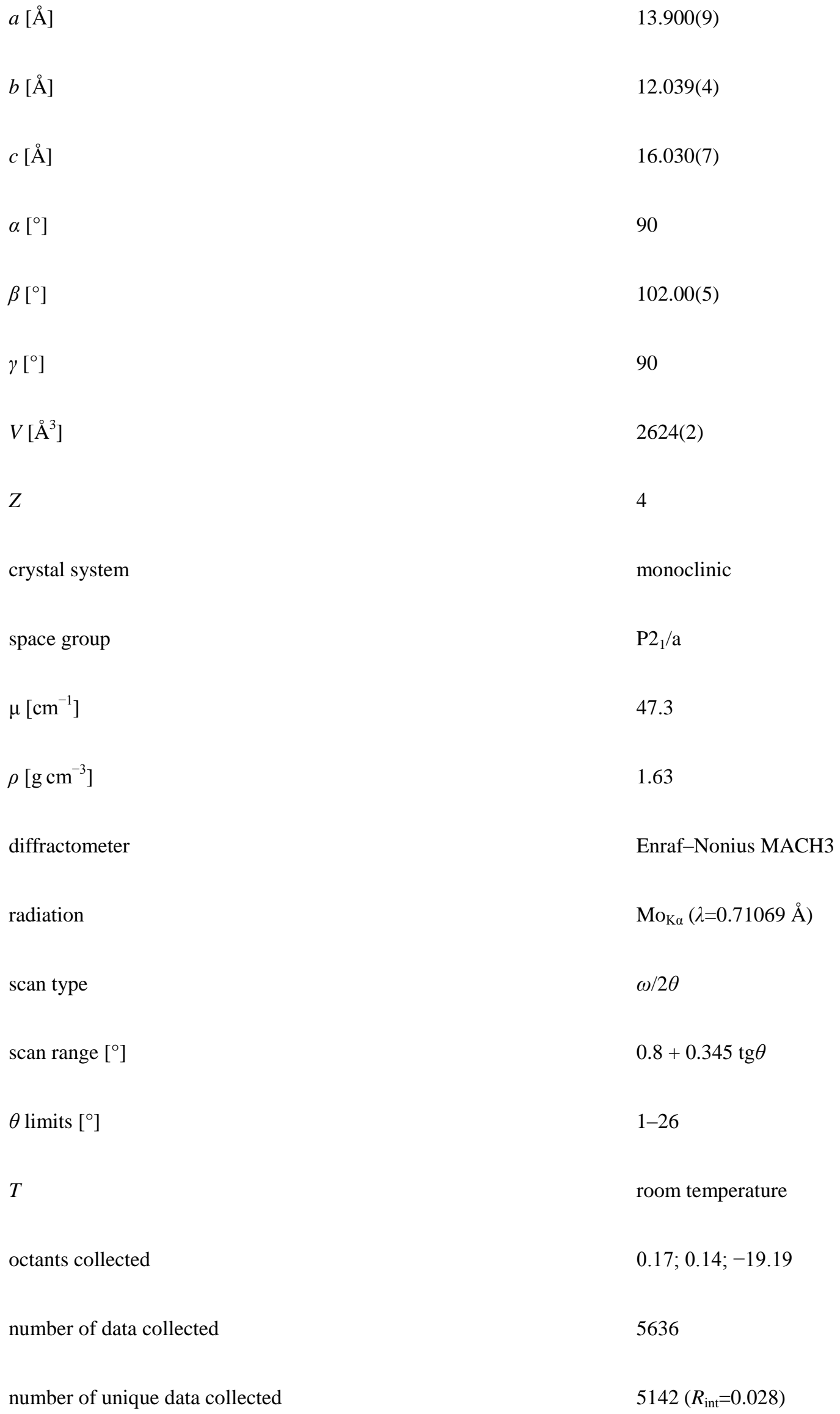




$\begin{array}{ll}\text { number of unique data used for refinement } & 2763\left(F_{\mathrm{o}}\right)^{2}>3 \sigma\left(F_{\mathrm{o}}\right)^{2} \\ R=\sum|| F_{\mathrm{o}}|-| F_{\mathrm{c}}|| \sum\left|F_{\mathrm{o}}\right| & 0.0420 \\ R w^{[\mathrm{a}]}=\left\{\sum w\left(\left|F_{\mathrm{o}}\right|-\left|F_{\mathrm{c}}\right|\right)^{2} / \sum^{w} F_{\mathrm{a}}^{2}\right\}^{1 / 2} & 0.0498 \\ \text { absorption correction } & \text { DIFABS (min }=0.88, \max =1) \\ \text { extinction parameter } & \text { none } \\ \text { goodness of fit } & 1.12 \\ \text { number of variables } & 317 \\ \Delta \rho_{\min }\left[\mathrm{e} \AA^{-3}\right] & -0.79 \\ \Delta \rho_{\max }\left[\mathrm{e} \AA^{-3}\right] & 1.12\end{array}$

[a] $w=w^{\prime}\left[1-\left(\left(|| F_{\mathrm{o}}|-| F_{\mathrm{c}} \|\right) / 6 \sigma\left(F_{\mathrm{o}}\right)\right)^{2}\right]^{2}$ with $w^{\prime}=1 / \sum r A_{r} T_{r}(X)$ with 3 coefficients $4.89,-2.13$ and 3.45 for a Chebyshev Series, for which $X$ is $F_{\mathrm{d}} / F_{\mathrm{c}}(\max )$.

It is interesting to compare the structure of $(E)-\mathbf{7} \mathbf{a}$ to that of ferrocifen $(\mathbf{2} \mathbf{a}){ }^{[12]}$ The $\mathrm{C}(1)$ $\mathrm{C}(2)$ bond length is $1.33(1) \AA$, which is shorter than that of $\mathbf{2} \mathbf{a}(1.37(2) \AA)$ but similar to that of tamoxifen (1.34 $\AA$ for the $Z$ isomer and $1.33 \AA$ for the $E$ isomer). ${ }^{[29]}$ The $\mathrm{C}(2)-\mathrm{C}(1)-\mathrm{C}(21)$ and $\mathrm{C}(2)-\mathrm{C}(1)-\mathrm{C}(31)$ angles are $123.5^{\circ}$ and $123.1^{\circ}$, respectively. While 2 a showed a little distortion by widening the $\mathrm{C}(1)-\mathrm{C}(2)-\mathrm{C}(11)$ angle $\left(129.0^{\circ}\right)$ and by narrowing the $\mathrm{C}(1)-\mathrm{C}(2)-\mathrm{C}(41)$ angle $\left(115.3^{\circ}\right),(E)-7$ a exhibits almost normal values of $124.4^{\circ}$ and $120.7^{\circ}$, respectively. It is clear that cyclopentadienyltricarbonylrhenium has a smaller steric effect on the $\alpha^{\prime}$ ring than ferrocene does in $\mathbf{2}$ a. The $\mathrm{C}-\mathrm{C}$ distance values in the double bond are in agreement with the observed order of ease of isomerisation. ${ }^{[30,31]}$

\section{Biochemical studies}

Measurement of the relative binding affinities (RBAs) of the complexes for the estrogen receptors ER $\alpha$ and ER $\beta$ : The rhenium complexes $7 \mathbf{a}-\mathbf{e}$ were tested as both $Z+E$ mixtures and separate $Z$ and $E$ isomers on the two forms of the estrogen receptor ER $\alpha$ (from cytosol and 
purified) and on the $\beta$ form of the receptor (purified), and the values were compared to those found for $\mathrm{OH}-$ Tam (1 b). These values are shown in Table 2.

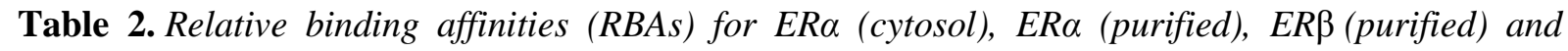
lipophilicity $\left(\log \mathrm{P}_{o / w}\right)$ of the rhenium derivatives of $\mathrm{OH}-\mathrm{Tam},(\mathrm{Z}+\mathrm{E})$ mixtures, and separated $\mathrm{Z}$ and $\mathrm{E}$ isomers. ${ }^{[a]}$

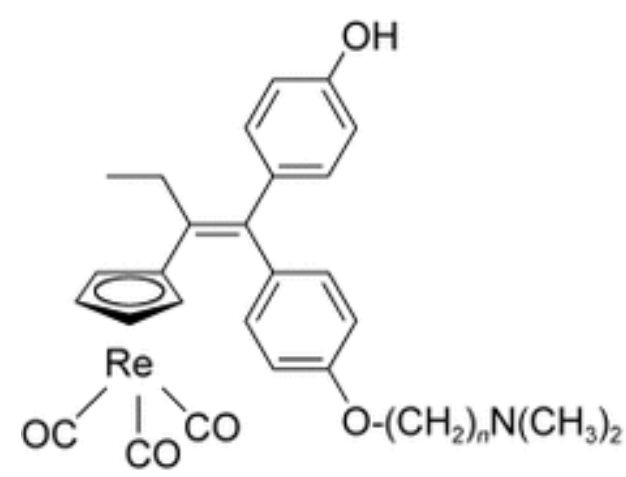

(Z)-7a-e

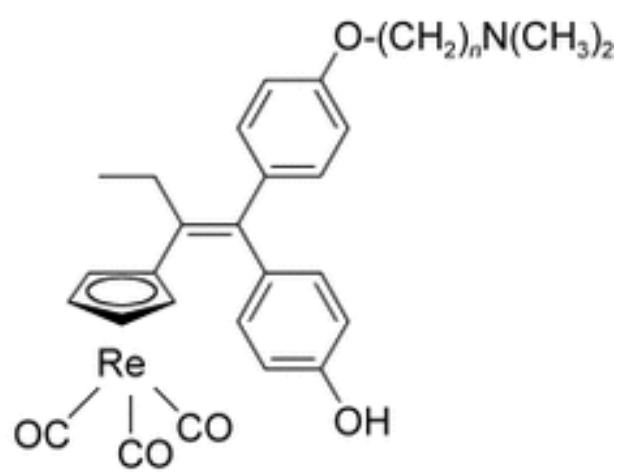

$(E)-7 a-e$
$\mathbf{E R \alpha}$
ERa
ERß
$\log P_{\text {o/w }}^{[b]}$

(cytosol)

(purified)

(purified)

$1 \mathrm{~b}$

$(Z+E)-\mathbf{1} \mathbf{b}$

$38.5^{[\mathrm{c}]}$

$24^{[\mathrm{cc}]}$

$(n=2)$

(Z)- 1 b

$107^{[\mathrm{c}]}$

-

$3.2^{[\mathrm{cc}]}$

7 a

$(Z+E)-7 \mathbf{a}$

$6.4 \pm 0.6$

$16.5 \pm 1.1^{[\mathrm{d}]}$

$9 \pm 0.1^{[\mathrm{d}]}$

$(n=2)$

(Z)- $7 \mathbf{a}$

$11.3 \pm 0.9$

$28 \pm 2$

$12 \pm 3$

4.5

(E)- $7 \mathbf{a}$

$3.5 \pm 0.1$

$4.0 \pm 0.5$

$5.1 \pm 0.8$

7 b

(Z)- $7 \mathbf{b}$

$12.3 \pm 0.2$

$31 \pm 3$

$16.8 \pm 0.2$

$(n=3)$

(E)- $7 \mathbf{b}$

$10.6 \pm 0.7$

$11.2 \pm 0.6$

$10.4 \pm 0.4$ 


\begin{tabular}{|c|c|c|c|c|c|}
\hline$(n=4)$ & $(Z)-7 \mathbf{c}$ & $7.4 \pm 0.2^{[d]}$ & $22.6 \pm 0.4$ & $18 \pm 1$ & 4.4 \\
\hline & $(E)-7 \mathbf{c}$ & $5.2 \pm 0.6$ & $3.6 \pm 0.6$ & $5.6 \pm 0.1$ & 4.6 \\
\hline $7 \mathrm{~d}$ & $(Z+E)-7 \mathbf{d}$ & $2 \pm 0.2$ & - & - & \\
\hline$(n=5)$ & (Z)- $7 \mathrm{~d}$ & $1.14 \pm 0.05$ & $16.0 \pm 2.6^{[d]}$ & $12 \pm 0.2$ & 4.7 \\
\hline & $(E)-7 \mathbf{d}$ & $1.13 \pm 0.05$ & $7.2 \pm 0.1$ & $6.7 \pm 0.1$ & 5.0 \\
\hline $7 \mathrm{e}$ & $(Z+E)-7 \mathbf{c}$ & $1.0 \pm 0.2$ & - & $1.6 \pm 0.1$ & \\
\hline$(n=8)$ & $(Z)-7 \mathrm{c}$ & $1.3 \pm 0.1$ & $2.9 \pm 0.5$ & $5 \pm 0.5$ & 6.0 \\
\hline & $(E)-7 \mathbf{c}$ & $0.7 \pm 0.1$ & $0.75 \pm 0.05$ & $2.7 \pm 0.5$ & 6.3 \\
\hline
\end{tabular}

[a] Measurements performed with stock solutions in DMSO for $3 \mathrm{~h}$ at $0{ }^{\circ} \mathrm{C}$. Mean of two experiments (general case) or three (when specified). [b] Measured by reversed- phase HPLC. [c] Value from ref. [17]. [d] Mean of three experiments.

The decrease in global recognition of the organometallic complexes of rhenium compared to $\mathrm{OH}-\mathrm{Tam}$ is primarily as a result of the greater steric hindrance of the $\mathrm{CpRe}(\mathrm{CO})_{3}$ moiety relative to the less bulky phenyl group of $\mathrm{OH}^{-}$Tam (see modelling studies below). However, the complexes remain reasonably well recognised by the two forms of the estrogen receptor, particularly in the case of $\mathbf{7} \mathbf{a}, \mathbf{7} \mathbf{b}$ and $7 \mathbf{c}(n=2,3$ and 4). As the chain is lengthened, the RBA value declines (in the case of $\mathbf{7} \mathbf{d}$ and $\mathbf{7 e} ; n=5$ and 8). In all cases the RBA values of the $Z$ isomers are higher than those for the $E$ isomers and the $Z+E$ mixture of the two isomers. This is also observed with $\mathrm{OH}-\mathrm{Tam}$. The difference is more marked when working with the purified receptors. The RBA values obtained for the $E$ isomers are the lowest but remain significant with a maximum of over $10 \%$ for $(E)-\mathbf{7} \mathbf{b}(n=3)$.

Determination of $\log \mathrm{P}_{o / w}$ values: The lipophilicity $\left(\log P_{\mathrm{o} / \mathrm{w}}\right.$ value) of the complexes was determined by reversed- phase HPLC. All the rhenium complexes have higher $\log P_{\mathrm{o} / \mathrm{w}}$ values than estradiol $\left(\log P_{\mathrm{o} / \mathrm{w}}=3.5\right)$ and the $Z$ and $E$ isomers of $\mathrm{OH}-\mathrm{Tam}\left(\log P_{\mathrm{o} / \mathrm{w}}=3.2\right.$ and 3.4 , 
respectively). Substitution of the phenyl group by a $\mathrm{CpRe}(\mathrm{CO})_{3}$ moiety increases the lipophilicity by 1.3 , which is in agreement with the result previously found for the estradiol series. ${ }^{[32]}$ Increasing the length of the side chain results in a progressive increase in the $\log P_{\mathrm{o} / \mathrm{w}}$ value. The values obtained for these rhenium complexes are very close to those found for the ferrocifens, except in the case of $n=2$. For any given pair of isomers, the $E$ isomer is always slightly more lipophilic than the $Z$ isomer.

Study of the antiproliferative effects of (Z)- and (E)- $7 \boldsymbol{b}$ and (Z)- and (E)- $7 \boldsymbol{d}$ on hormone- dependent (MCF7) and hormone- independent (MDA-MB231) breast cancer cell lines: Separation of the $Z$ and $E$ isomers of all the rhenium complexes $7 \mathbf{a}-\mathbf{e}$ was carried out by preparative reversed- phase HPLC. Since we have previously shown that these complexes do not isomerise in solution, we have chosen two representative pairs of isomers, $(Z)$ - and (E)- $\mathbf{7 b}$ and $\mathbf{7 d}$, to study their proliferative/antiproliferative effect on the MCF7 and MDA- MB231 cell lines, which are considered the archetypes of $\operatorname{ER} \alpha(+)$ and $\operatorname{ER} \alpha(-)$ cell lines, respectively. OH- Tam (1 b) and estradiol were added as controls in each series. The results obtained are shown in Figures 2 and 3.

At an incubation molarity of $1 \mu \mathrm{M}$, the two isomers (Z)- and $(E)-\mathbf{7} \mathbf{b}$ and $\mathbf{7} \mathbf{d}$ have an antiproliferative effect on MCF7 cells which is slightly higher (12-15\%) than that of $\mathrm{OH}$ - Tam. In both series ( $n=3$ and $n=5$ ), the $Z$ isomer is more effective than the $E$ isomer. However, the observed difference is quite modest at around $5 \%$ (Figure 2). This antiproliferative effect of the complexes must, like that of $\mathrm{OH}-\mathrm{Tam}$, be linked to an antiestrogenic effect. However, the significant differences in RBA values of $\mathbf{7} \mathbf{b}$ and $\mathbf{7} \mathbf{d}$ found for cytosolic ER are not reflected in any great variation in antiproliferative effects on these hormone- dependent cells.

As expected, on MDA- MB231 cells with no ER $\alpha$, neither estradiol nor OH- Tam has any effect (Figure 3). At a concentration of $1 \mu \mathrm{M}$, the rhenium complexes have a weak antiproliferative effect of $10 \%$ or slightly above. This antiproliferative effect must be associated with a cytotoxic effect, and the complexes with the longest chain $(n=5)$ are somewhat more effective than those with a 3-carbon chain. On these cells, the $Z$ and $E$ isomers have identical behaviour for any given pair. 


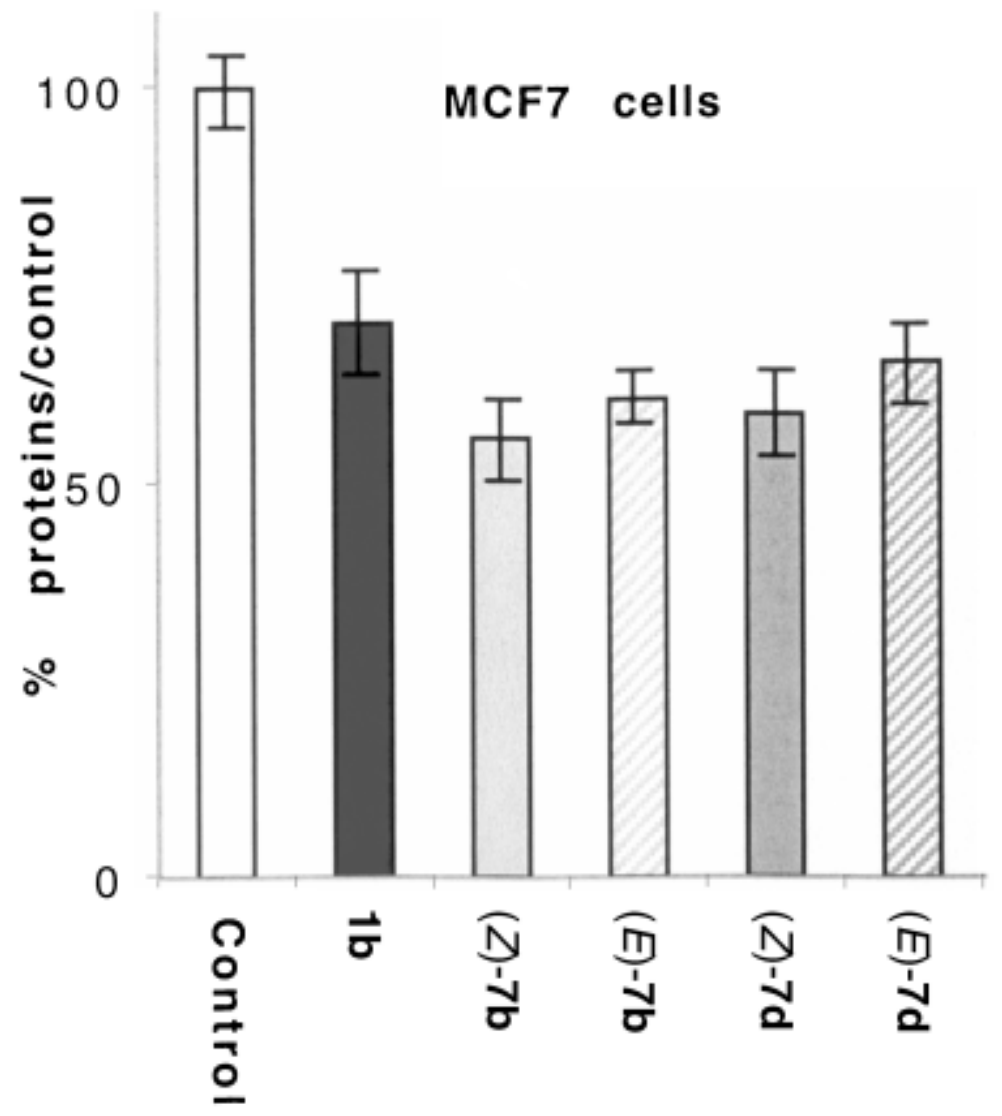

Figure 2 Antiproliferative effect of $1 \mu M$ of $O H$ - Tam $(\mathbf{1} \boldsymbol{b}),(Z)-7 \boldsymbol{b},(E)-7 \boldsymbol{b},(Z)-7 \boldsymbol{d}$ and (E)- $7 \boldsymbol{d}$ on MCF7 cells (breast cancer cell line ER $\alpha$-positive) after 6 days of culture. In this experiment $10 \mathrm{nM}$ of $E_{2}$ has a proliferative effect (198\%; data not shown). Representative data of one experiment performed twice with similar results ( 8 measurements \pm limits of confidence; $\mathrm{P}=0.1, \mathrm{t}=1.895$ ).

Overall the results obtained with these stable and lipophilic rhenium complexes are essentially linked to an antiestrogenic effect of the same order as or slightly higher than that of $\mathrm{OH}-\mathrm{Tam}$. This augurs well for the future introduction of active group- VII radionucleides to create another functionality in the binding site. 


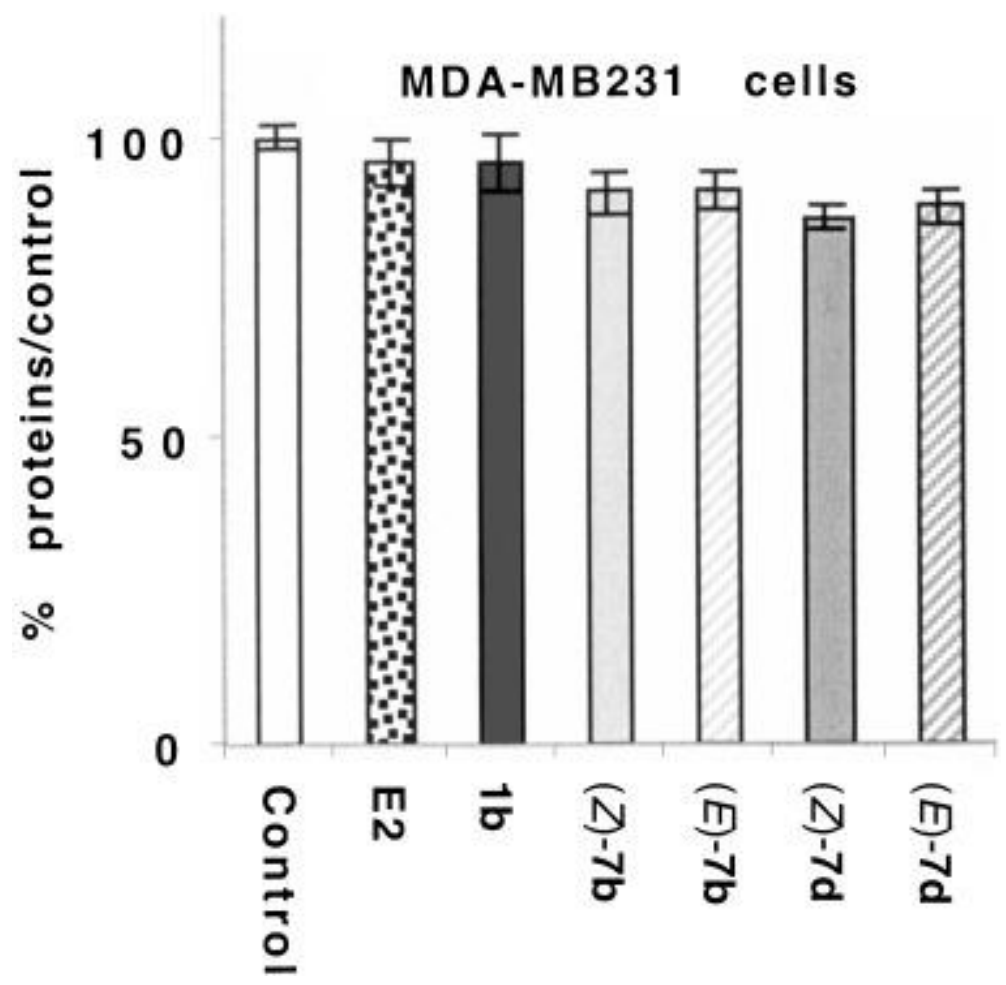

Figure 3 Effect of $1 \mu M$ of $O H-T a m(1 \boldsymbol{b}),(Z)-7 \boldsymbol{b},(E)-7 \boldsymbol{b},(Z)-7 \boldsymbol{d},(E)-7 \boldsymbol{d}$ and of 10 nM of $E_{2}$ on MDA-MB231 cells (breast cancer cell line ER $\alpha$ - negative) after 6 days of culture. Representative data of one experiment performed twice with similar results ( 8 measurements \pm limits of confidence; $\mathrm{P}=0.1, \mathrm{t}=1.895)$.

\section{Discussion}

The behavioural similarity between the rhenium complexes $\mathbf{7} \mathbf{b}$ and $\mathbf{7} \mathbf{d}$ and $\mathrm{OH}-\mathrm{Tam}(\mathbf{1} \mathbf{b})$ justifies the use of the crystallographic data underpinning the biological behaviour of OH- Tam. In particular, the structure of the ligand binding domain (LBD) of human estrogen receptor alpha $(\mathrm{hER} \alpha)$ occupied by $\mathrm{OH}-\mathrm{Tam}(\mathbf{1} \mathbf{b})$ has been published. ${ }^{[9]} \mathrm{We}$ digitally removed the bioligand $\mathbf{1} \mathbf{b}$ from the site and replaced it with $(Z)-\mathbf{7} \mathbf{b}$. To obtain Figure 4, we used MacSpartan Pro, ${ }^{[33]}$ Molview, ${ }^{[34]}$ and weblab viewer Accelys ${ }^{35}$ software successively. This molecular modelling study shows the overall position of $(Z)-\mathbf{7} \mathbf{b}$ in the binding site with the phenol of (Z)- $\mathbf{7} \mathbf{~ b}$ bound to the amino acid residues Arg- 394 and Glu- 353, while Asp- 351 reveals the possibility of a hydrogen bond with the nitrogen atom of the basic chain $\mathrm{O}-\left(\mathrm{CH}_{2}\right)_{3} \mathrm{NMe}_{2}$. The $\mathrm{CpRe}(\mathrm{CO})_{3}$ moiety which replaces the phenyl of $\mathbf{1} \mathbf{b}$ is easily inserted at the level of His- 524 causing no notable perturbation. This view shows the steric influence of the basic chain at the level of helix 12 of the protein. The latter can no longer bind to helix 4 , and this new conformation prevents fixation of the coactivators present. This new position 
of H12, which is stabilised by the bond between Asp- 351 and the nitrogen atom of the $\mathrm{NMe}_{2}$ group of the side chain, is responsible, as with $\mathrm{OH}-\mathrm{Tam}$, for the antagonist effect observed with the MCF7 cell line.

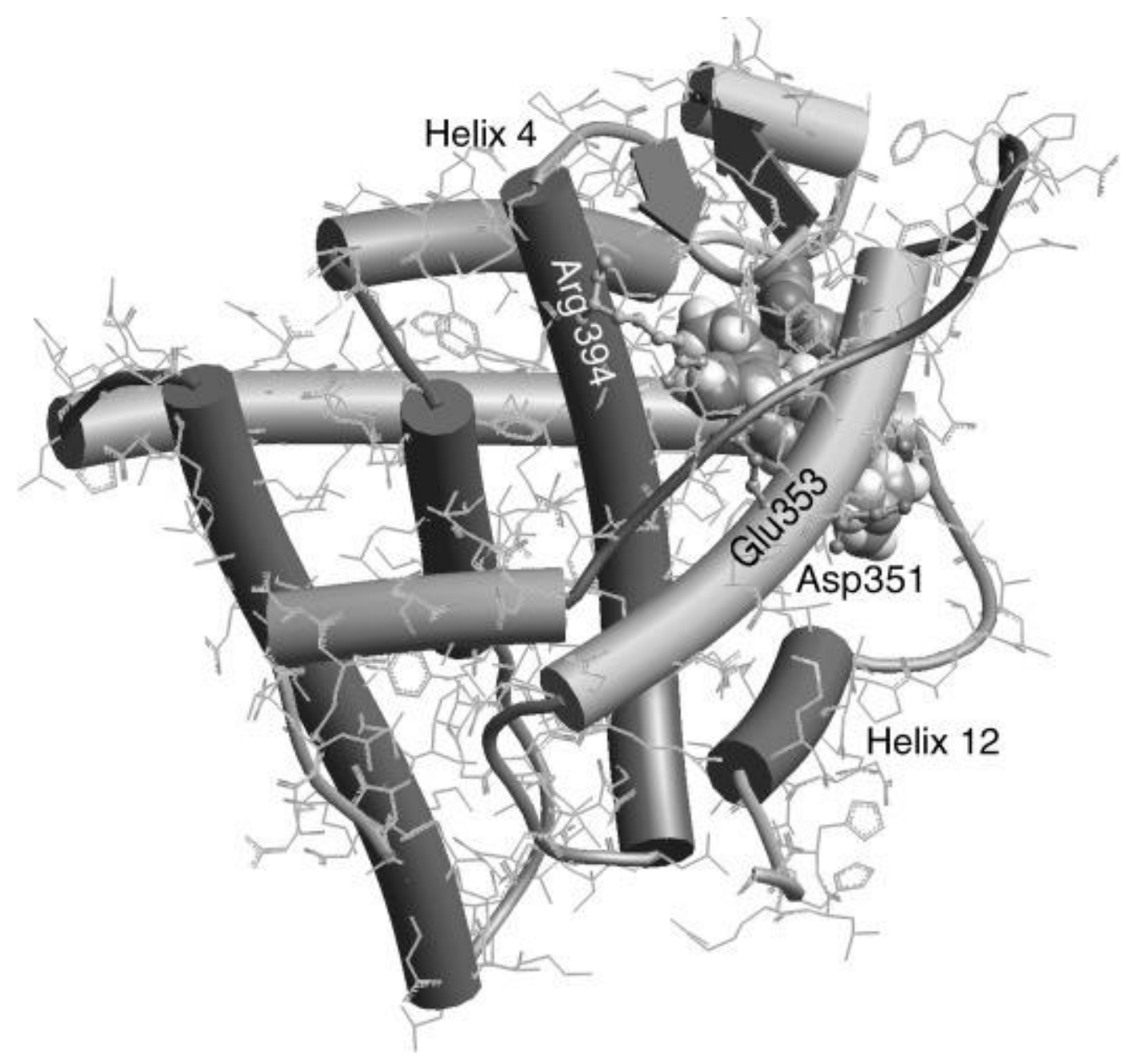

Figure 4 View of (Z)- $7 \boldsymbol{b}$ docked in the antagonist binding site of hER $\alpha$. This view is based on the ligand binding site $X$ - ray structural determination obtained by Shiau ${ }^{[9]}$ and the use of several computer programs. ${ }^{[33-35]}$ For an explanation see text.

A more detailed molecular modelling study reveals the precise role played by the organometallic moiety, which in this case is based solely on the steric effect, in contrast to the case of the ferrocifens for which the possibility of oxidation of the ferrocene came into play. ${ }^{[17]}$ Here, once again, we used MacSpartan Pro ${ }^{[33]}$ software and the LBD structure published by Shiau. ${ }^{[9]}$ Only the amino acids forming the wall of the cavity were retained, 
totalling 757 atoms. OH- Tam was removed and replaced with the rhenium complexes $\mathbf{7} \mathbf{b}$ with $Z$ and $E$ geometry, and with a 3- carbon side chain. With all the heavy atoms of the cavity immobilised, a position search was carried out to determine the energetically optimal location for the mediator. Next, the side chain of the amino acid Met- 343, which represented a steric hindrance for the organometallic moiety, was liberated. This was justified by the fact that this part of the cavity has been shown to be flexible. ${ }^{[36]}$ An energy minimisation was then carried out with all the heavy atoms immobilised, except those of the mediator and of the Met- 343 side chain, by using the Merck molecular force field (MMFF). A conformational study was also carried out inside the cavity to determine the best position for the organometallic moiety in relation to the rest of the molecule. This determined the ideal position for the bioligand. Next, the affinity of the bioligand for its cavity was determined by MMFF molecular mechanics, with calculations for the bioligand-cavity combination, and for the cavity and bioligand separately, with the last two retaining the conformations they had in the molecular complex. This gives the $\Delta E$ energy change for the reaction bioligand + cavity $\rightarrow$ molecular complex. This gives a result of $\Delta E=-42 \mathrm{kcal} \mathrm{mol}^{-1}$ for (Z)- $7 \mathbf{b}$ and $\Delta E=-36 \mathrm{kcal} \mathrm{mol}^{-1}$ for $(E)-7 \mathbf{b}$. The calculation shows that these compounds have good affinity for the cavity in agreement with the RBA values obtained. Recognition of hER $\alpha$ is better for the $Z$ than the $E$ isomer, despite the fact that these two compounds have identical volumes ( $483 \AA^{3}$ for $(Z)-7$ b and $484 \AA^{3}$ for $(E)$ - $7 \mathbf{b}$ ). The difference in affinity lies in the fact that the $Z$ isomer is a better fit for the shape of the cavity than its geometric $E$ isomer (Figure 5). 

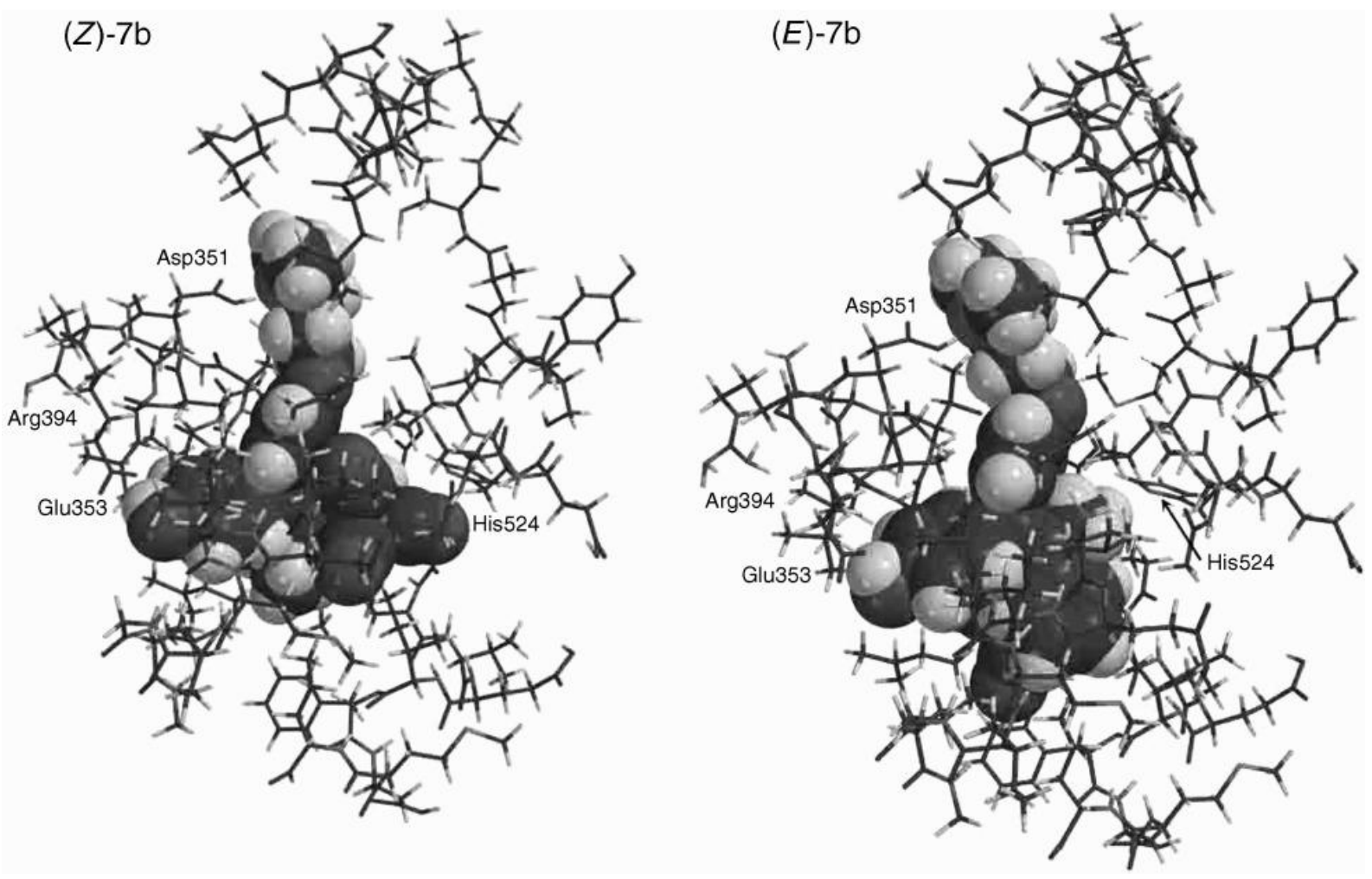

Figure 5 Space-filling models of (Z)- $7 \boldsymbol{b}$ and (E)- $7 \boldsymbol{b}$ in the ligand binding site of the antagonist form of the ER $\alpha$ as a basis for the structure previously described by Shiau. ${ }^{[9]}$

Calculations of $\Delta E$ for a 2- carbon chain give $\Delta E=-38 \mathrm{kcal} \mathrm{mol}^{-1}$ for $(Z)-7$ a and $\Delta E=-33$ $\mathrm{kcal} \mathrm{mol}^{-1}$ for $(E)-7 \mathbf{a}$. Here again, the results are in accord with the RBA values. The reason for this is that the organometallic moiety $\mathrm{CpRe}(\mathrm{CO})_{3}$ fills the volume of the cavity well. The molecule has little room for free play at this level. Because of these constraints the 2- carbon chain at the other end of the molecule does not optimally stabilise the hydrogen bond with Asp- 351. The situation is completely different with (Z)- OH- Tam (1 b). This molecule is less bulky, with a volume of only $395 \AA^{3}$. Consequently, the phenyl does not by any means occupy the entire cavity. This makes it possible for the molecule to adjust its position at this level, and a 2- carbon chain is sufficient to give a good bond with Asp- 351 and to stabilise the system. A similar rationale is applicable to the case of the ferrocifens, for which the antiproliferative effects with MCF7 cells are better with a 3- carbon than with a 2- carbon chain. ${ }^{[17,37]}$ This modelling study is consistent with the published body of work involving hER $\alpha$.

For hER $\beta$, the available structural data are still insufficient to allow this type of molecular approach. ${ }^{[7]}$ As a first approximation the results obtained with MDA- MB231 are weak to 
nonexistent, similar to those of $\mathrm{OH}-$ Tam $(\mathbf{1} \mathbf{b})$. It is possible that the primary target here is estrogen receptor $\beta$, for which, to the best of our knowledge, there has been no X- ray structural determination of the LBD with $\mathrm{OH}-$ Tam $(\mathbf{1} \mathbf{b})$ bound to the site. The fact that there is a slight variation in the effect depending on the length of the chain $7 \mathbf{c}(n=4)$ suggests that other targets of tamoxifen, such as the calmodulin receptor, may be partially involved. ${ }^{[38]}$

Since one of the future aims of this program is to find a route to ${ }^{99 \mathrm{~m}} \mathrm{Tc}-$ labelled radiopharmaceuticals analogous to $(Z)-\mathbf{7} \mathbf{b}$, we carried out a $\Delta E$ energy variation calculation with this hypothetical technetium molecule and found a variation of $\Delta E=-36 \mathrm{kcal} \mathrm{mol}^{-1}$. The result allows us to predict that this radioactive complex should have good affinity for the estrogen receptor, and will be an attractive target molecule to synthesise.

\section{Conclusion}

These results reveal a striking analogy between the biochemical behaviour of $\mathrm{OH}$ - Tam and its organometallic rhenium analogues. The differences between the two series are attributable to the greater volume of $\mathrm{CpRe}(\mathrm{CO})_{3}$ compared to the $\beta$ - phenyl of $\mathrm{OH}-\mathrm{Tam}(\mathbf{1} \mathbf{b})$ which was substituted. This is very clear in the molecular modelling studies in which moderate lengthening of the basic chain retrieves the initial effect. The (Z)- $\mathbf{7} \mathbf{b}$ complex represents the best compromise between recognition and activity.

Based on the results of this study, and assuming that $\mathrm{CpRe}(\mathrm{CO})_{3}$ does not play a functional role in the site, the effect of the rhenium antiestrogens at the level of estrogen receptor alpha is entirely conformational in nature. The basic carbon chain plays the same role as its equivalent in $\mathrm{OH}-\mathrm{Tam}$ : it changes the conformation of helix 12 of $\mathrm{ER} \alpha$, thus causing an antagonist effect. MDA- MB231 cells contain no receptor $\alpha$ but only the $\beta$ form of the estrogen receptor. Here again, the observed lack of effect is analogous to that of OH- Tam, and for the same reasons. ${ }^{[7]}$ The slight chain effect observed may perhaps be compared to the intervention of a partial inhibition mechanism of the calmodulin receptor. ${ }^{[38]}$

Our results clearly demonstrate the approach to be followed in making use of this type of product in the future: it is a case of functionalising the $\mathrm{CpRe}(\mathrm{CO})_{3}$ moiety of the vectors 7 . There are two objectives: either to prepare a complex of the $\mathrm{Cp}^{99 \mathrm{~m}} \mathrm{Tc}(\mathrm{CO})_{3}$ type, a $\gamma$ emitter for use in medical imaging; or to prepare $\mathrm{Cp}^{188} \operatorname{Re}(\mathrm{CO})_{3}$, also on the vectors 7 , to give a novel therapeutic product based on $\beta$ emission. The chemistry is identical in either case. It is still necessary, however, to find novel reactions that are rapid, high- yielding and usable in 
water. ${ }^{[24-26]}$ We are actively working on this. In particular, we are exploring two routes, one involving use of Alberto's reagent $\left[\left(\mathrm{H}_{2} \mathrm{O}\right)_{3} \mathrm{Re}(\mathrm{CO})_{3}\right]^{+}$or $\left[\left(\mathrm{H}_{2} \mathrm{O}\right)_{3} \mathrm{Tc}(\mathrm{CO})_{3}\right]^{+},{ }^{[39-42]}$ the other a novel exchange reaction between $\left[\operatorname{Re}(\mathrm{CO})_{6}\right]^{+}$and the ferrocene derivatives developed in our laboratory. ${ }^{[43]}$ The first results are encouraging, as we have successfully developed a one- step synthesis of a ${ }^{99 m} \mathrm{Tc}$ - labelled steroid. This molecule is obtained by exchange of a ferrocene with a $\mathrm{Cp}^{99 \mathrm{~m}} \mathrm{Tc} / \mathrm{Re}(\mathrm{CO})_{3}$ moiety. The reaction gives high yields of $>90 \%$ at $95^{\circ} \mathrm{C}$ in a $\mathrm{H}_{2} \mathrm{O}$ /dimethyl sulfoxide (DMSO) mixture in $3.5 \mathrm{~h}$ (Scheme 2). ${ }^{[44]}$

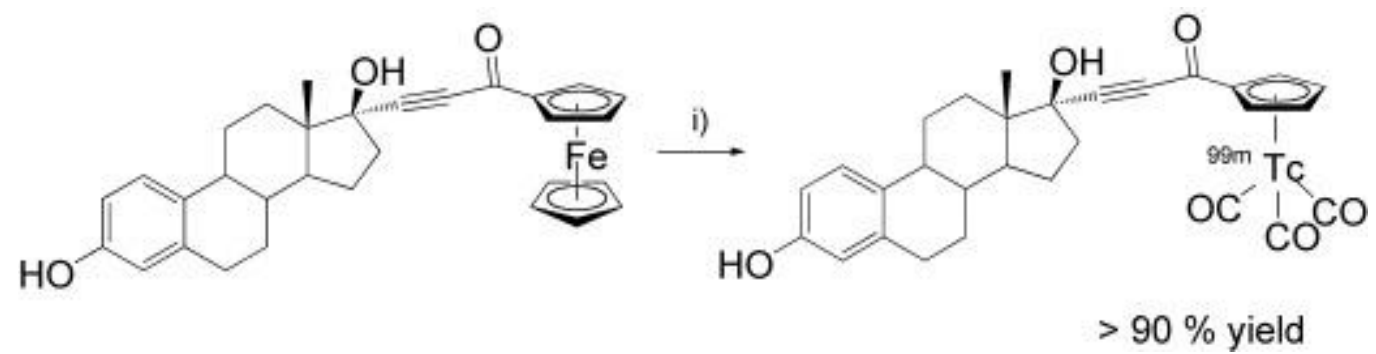

Scheme 2 Synthesis of a novel, ${ }^{99 m} \mathrm{Tc}$-labelled $17 \alpha$-ethynylestradiol derivative: i) $\left[^{99 m} \mathrm{Tc}_{\mathrm{c}}\left(\mathrm{H}_{2} \mathrm{O}\right)_{3}(\mathrm{CO})_{3}\right]^{+}$in $\mathrm{H}_{2} \mathrm{O} / \mathrm{DMSO} 1: 1$ mixture, $95^{\circ} \mathrm{C}, 3.5$ h at atmospheric pressure. ${ }^{[44]}$

\section{Experimental Section}

General: Starting materials were synthesized by using standard Schlenk techniques under an argon atmosphere. Anhydrous THF and diethyl ether were distilled from sodium/benzophenone. Thin- layer chromatography was performed on silica gel 60 GF254. FTIR spectra of $\mathrm{KBr}$ plates were recorded on a BOMEM Michelson- 100 spectrophotometer. ${ }^{1} \mathrm{H}$ and ${ }^{13} \mathrm{C}$ NMR spectra were acquired on Bruker 200 and Bruker 400 spectrometers by using $\mathrm{CDCl}_{3}$ as a solvent. Mass spectrometry was performed on a Nermag $\mathrm{R}$ 10-10C spectrometer. Melting points were measured with a Kofler device. Elemental analyses were performed by the Regional Microanalysis Department of the Universite Pierre et Marie Curie.

4- Halogenoalkoxyphenyl- 4'- hydroxyphenyl ketones $4 \mathrm{a}$ : Potassium hydride $(5.70 \mathrm{~g}$ of $35 \%$ dispersion in oil, $50 \mathrm{mmol}$ ) was introduced into a Schlenk tube filled with argon. The mixture was washed three times with petroleum ether, and then the rest of the petroleum ether was evaporated under reduced pressure for $10 \mathrm{~min}$. Dry THF $(100 \mathrm{~mL})$ was added. A solution 
of 4,4'- dihydroxybenzophenone (10.7 g, $50 \mathrm{mmol})$ in $N, N$ - dimethylformamide $(200 \mathrm{~mL})$ was carefully added with a syringe. The yellow mixture was heated for $10 \mathrm{~min}$ and then cooled. Dibromoethane $(250 \mathrm{mmol})$ was rapidly added, and the mixture was then heated again at gentle reflux overnight. The solution was cooled, and the solvent was removed under reduced pressure. The residue was purified by column chromatography with silica gel using dichloromethane/acetone (95:5) as eluent. Recrystallization from dichloromethane furnished pure ketone 4 a (12\% yield). M.p. $141^{\circ} \mathrm{C}$; IR (KBr): $\bar{v}=3183(\mathrm{OH}), 1600 \mathrm{~cm}^{-1}(\mathrm{C}=\mathrm{O}) ;{ }^{1} \mathrm{H}$ NMR: $\delta=3.68\left(\mathrm{t}, J=6.2 \mathrm{~Hz}, 2 \mathrm{H} ; \mathrm{CH}_{2}\right), 4.38\left(\mathrm{t}, J=6.2 \mathrm{~Hz}, 2 \mathrm{H} ; \mathrm{CH}_{2}\right), 6.93(\mathrm{~d}, J=8.9 \mathrm{~Hz}, 2 \mathrm{H}$; $\mathrm{H}_{\text {arom }}$ ), 6.98 (d, J=8.8 Hz, $\left.2 \mathrm{H} ; \mathrm{H}_{\text {arom }}\right), 7.05$ (s, $\left.1 \mathrm{H} ; \mathrm{OH}\right), 7.74$ (d, J=8.8 Hz, $2 \mathrm{H} ; \mathrm{H}_{\text {arom }}$ ), 7.79 ppm $\left(\mathrm{d}, J=8.9 \mathrm{~Hz}, 2 \mathrm{H} ; \mathrm{H}_{\text {arom }}\right) ;{ }^{13} \mathrm{C}$ NMR: $\delta=28.5\left(\mathrm{CH}_{2}\right), 67.8\left(\mathrm{CH}_{2}\right), 114.1(2 \mathrm{CH}), 115.1$ (2 CH), $130.0(\mathrm{C}), 131.1(\mathrm{C}), 132.3$ (2 CH), 132.6 (2 CH), $160.1(\mathrm{C}), 161.4(\mathrm{C}), 195.2$ ppm (CO); MS (IE, $70 \mathrm{eV}): \mathrm{m} / \mathrm{z}: 320[M]^{+}$.

Alkene 6 a: Titanium tetrachloride $(2 \mathrm{~mL}, 18 \mathrm{mmol})$ was added dropwise to a suspension of zinc powder $(2.34 \mathrm{~g}, 36 \mathrm{mmol})$ in THF $(60 \mathrm{~mL})$ at $0{ }^{\circ} \mathrm{C}$. The mixture obtained was heated at reflux for $2 \mathrm{~h}$ and then allowed to cool to room temperature. A second solution was prepared by dissolving 4- haloalkoxy- 4'- hydroxybenzophenone (4 a) $(6 \mathrm{mmol})$ and ketone 5 (2.35 g, $6 \mathrm{mmol})$ in THF $(30 \mathrm{~mL})$. This latter solution was added dropwise to the first solution, and the resulting mixture was then heated at reflux for $2 \mathrm{~h}$. After cooling to room temperature, the mixture was stirred with water and dichloromethane. The mixture was acidified with dilute hydrochloric acid, filtered (Celite), and the organic layer was dried over magnesium sulfate. After concentration under reduced pressure, the crude product was purified by chromatography on silica gel plates with dichloromethane as eluent to give a pure mixture of $6 \mathbf{a}\left(Z+E, 64 \%\right.$ yield) as an oil. IR (KBr): $\bar{v}=3422(\mathrm{OH}), 2018$ and $1920 \mathrm{~cm}^{-1}(\mathrm{C}=\mathrm{O})$; MS (IE, $70 \mathrm{eV}$ ): $\mathrm{m} / z: 680[M]^{+}, 596[M-3 \mathrm{CO}]^{+}$; Major isomer: ${ }^{1} \mathrm{H}$ NMR: $\delta=1.06(\mathrm{t}, J=7.5 \mathrm{~Hz}$, $\left.3 \mathrm{H} ; \mathrm{CH}_{3}\right), 2.26$ (q, J=7.5 Hz, $\left.2 \mathrm{H} ; \mathrm{CH}_{2}\right), 3.63\left(\mathrm{t}, J=6.2 \mathrm{~Hz}, 2 \mathrm{H} ; \mathrm{CH}_{2}\right), 4.28$ (t, J=6.2 Hz, $2 \mathrm{H}$; $\left.\mathrm{CH}_{2}\right), 5.01-5.16\left(\mathrm{~m}, 4 \mathrm{H} ; \mathrm{C}_{5} \mathrm{H}_{4}\right), 6.68-7.15 \mathrm{ppm}\left(\mathrm{m}, 8 \mathrm{H} ; \mathrm{H}_{\text {arom }}\right) ;{ }^{13} \mathrm{C}$ NMR: $\delta=15.2\left(\mathrm{CH}_{3}\right)$, $29.1\left(\mathrm{CH}_{2}\right), 30.8\left(\mathrm{CH}_{2}\right), 67.7\left(\mathrm{CH}_{2}\right), 82.7\left(2 \mathrm{CH}, \mathrm{C}_{5} \mathrm{H}_{4}\right), 85.6\left(2 \mathrm{CH}, \mathrm{C}_{5} \mathrm{H}_{4}\right), 108.9\left(1 \mathrm{C}_{,} \mathrm{C}_{5} \mathrm{H}_{4}\right)$, $114.4(2 \mathrm{CH}), 115.5(2 \mathrm{CH}), 130.0(2 \mathrm{CH}), 130.4(\mathrm{C}), 130.6(2 \mathrm{CH}), 135.5(\mathrm{C}), 136.3(\mathrm{C})$, 141.9 (C), 154.9 (C), 156.8 (C), 194.6 ppm (3 CO); Minor isomer: ${ }^{1} \mathrm{H}$ NMR: $\delta=1.06$ (t, $J=7.5$ $\mathrm{Hz}, 3 \mathrm{H} ; \mathrm{CH}_{3}$ ), 2.27 (q, J=7.5 Hz, $2 \mathrm{H} ; \mathrm{CH}_{2}$ ), 3.63 (t, J=6.2 Hz, $2 \mathrm{H} ; \mathrm{CH}_{2}$ ), 4.26 (t, J=6.2 Hz, $\left.2 \mathrm{H} ; \mathrm{CH}_{2}\right), 5.01-5.16\left(\mathrm{~m}, 4 \mathrm{H} ; \mathrm{C}_{5} \mathrm{H}_{4}\right), 6.68-7.15 \mathrm{ppm}\left(\mathrm{m}, 8 \mathrm{H} ; \mathrm{H}_{\text {arom }}\right) ;{ }^{13} \mathrm{C}$ NMR: $\delta=15.2$ $\left(\mathrm{CH}_{3}\right), 29.1\left(\mathrm{CH}_{2}\right), 30.8\left(\mathrm{CH}_{2}\right), 67.7\left(\mathrm{CH}_{2}\right), 82.7\left(2 \mathrm{CH}, \mathrm{C}_{5} \mathrm{H}_{4}\right), 85.6\left(2 \mathrm{CH}, \mathrm{C}_{5} \mathrm{H}_{4}\right), 108.9(1 \mathrm{C}$, 
$\left.\mathrm{C}_{5} \mathrm{H}_{4}\right), 114.7(2 \mathrm{CH}), 115.2(2 \mathrm{CH}), 130.0(2 \mathrm{CH}), 130.4(\mathrm{C}), 130.6(2 \mathrm{CH}), 135.2(\mathrm{C}), 136.6$ (C), 141.9 (C), 154.7 (C), 156.9 (C), 194.6 ppm (3 CO).

Amine 7 a: Halide 6 a ( $3 \mathrm{mmol})$ was added to a solution of dimethylamine in methanol ( $2 \mathrm{M}$, $15 \mathrm{~mL}, 30 \mathrm{mmol}$ ) and placed in an autoclave. The mixture was heated with stirring at $60^{\circ} \mathrm{C}$ for 1 day. After cooling, the solution was concentrated under reduced pressure. The residue was purified by chromatography on silica gel plates (chloroform/triethylamine, 80:20 as eluent). After evaporation of the solvent, the residue obtained was dissolved in dichloromethane, and the solution was washed three times with water. The organic layer was dried over magnesium sulfate, and the solution was then concentrated under reduced pressure to furnish a pure mixture of $Z$ and $E$ isomers of $\mathbf{7}$ a as an oil. The $Z$ and $E$ isomers (ratio $18: 82$, respectively; $82 \%$ yield) were separated on a reverse- phase semipreparative Kromasil $\mathrm{C} 18$ column (diameter $2 \mathrm{~cm}$, length $25 \mathrm{~cm}$ ), eluent methanol/phosphate buffer $\left(\mathrm{KH}_{2} \mathrm{PO}_{4}, 25\right.$ $\mathrm{mM}, \mathrm{pH} 7)$, flow rate $6 \mathrm{~mL} \mathrm{~min}^{-1}$. Major (E) isomer: m.p. $141^{\circ} \mathrm{C}$; IR (KBr): $\bar{v}=3449(\mathrm{OH})$, 2016 and $1913 \mathrm{~cm}^{-1}(\mathrm{C}=\mathrm{O})$; ${ }^{1} \mathrm{H}$ NMR: $\delta=1.04$ (t, $\left.J=7.4 \mathrm{~Hz}, 3 \mathrm{H} ; \mathrm{CH}_{3}\right), 2.29$ (q, $J=7.4 \mathrm{~Hz}, 2 \mathrm{H}$; $\mathrm{CH}_{2}$ ), 2.43 (s, $6 \mathrm{H} ; \mathrm{NMe}_{2}$ ), 2.83 (t, J=5.3 Hz, $2 \mathrm{H} ; \mathrm{NCH}_{2}$ ), 4.04 (t, J=5.3 Hz, $2 \mathrm{H} ; \mathrm{OCH}_{2}$ ), 5.11 (s, $\left.4 \mathrm{H} ; \mathrm{C}_{5} \mathrm{H}_{4}\right), 6.48$ (d, J=8.7 Hz, $\left.2 \mathrm{H} ; \mathrm{H}_{\text {arom }}\right), 6.71$ (d, J=8.6 Hz, $\left.2 \mathrm{H} ; \mathrm{H}_{\text {arom }}\right), 6.91$ (d, J=8.6 $\left.\mathrm{Hz}, 2 \mathrm{H} ; \mathrm{H}_{\text {arom}}\right), 6.97 \mathrm{ppm}\left(\mathrm{d}, J=8.7 \mathrm{~Hz}, 2 \mathrm{H} ; \mathrm{H}_{\text {arom }}\right) ;{ }^{13} \mathrm{C}$ NMR: $\delta=15.3\left(\mathrm{CH}_{3}\right), 29.1\left(\mathrm{CH}_{2}\right)$, $45.0\left(2 \mathrm{CH}_{3}\right), 58.0\left(\mathrm{CH}_{2}\right), 64.1\left(\mathrm{CH}_{2}\right), 82.6\left(2 \mathrm{CH}, \mathrm{C}_{5} \mathrm{H}_{4}\right), 85.4\left(2 \mathrm{CH}, \mathrm{C}_{5} \mathrm{H}_{4}\right), 109.8(1 \mathrm{C}$, $\left.\mathrm{C}_{5} \mathrm{H}_{4}\right), 113.7$ (2 CH), $115.9(2 \mathrm{CH}), 129.5(\mathrm{C}), 130.0(2 \mathrm{CH}), 130.8(2 \mathrm{CH}), 134.6(\mathrm{C}), 135.7$ (C), 142.4 (C), 156.2 (C), 157.3 (C), 194.7 ppm (3 CO); MS (IE, $70 \mathrm{eV}$ ): m/z: $645[M]^{+}, 561$ $[M-3 \mathrm{CO}]^{+}$; elemental analysis calcd (\%) for $\mathrm{C}_{28} \mathrm{H}_{28} \mathrm{NO}_{5} \mathrm{Re}$ : C 52.16, H 4.38, N 2.17; found: C 51.53, H 4.51, N 2.16; Minor (Z) isomer: m.p. $110^{\circ} \mathrm{C}$; IR (KBr): $\bar{v}=3438(\mathrm{OH}), 2016$ and $1913 \mathrm{~cm}^{-1}(\mathrm{C}=\mathrm{O})$; ${ }^{1} \mathrm{H}$ NMR: $\delta=1.07$ (t, $\left.J=7.4 \mathrm{~Hz}, 3 \mathrm{H} ; \mathrm{CH}_{3}\right), 2.31$ (q, $J=7.4 \mathrm{~Hz}, 2 \mathrm{H} ; \mathrm{CH}_{2}$ ), $2.42\left(\mathrm{~s}, 6 \mathrm{H} ; \mathrm{NMe}_{2}\right), 2.82\left(\mathrm{t}, J=5.3 \mathrm{~Hz}, 2 \mathrm{H} ; \mathrm{NCH}_{2}\right), 4.04$ (t, J=5.3 Hz, $\left.2 \mathrm{H} ; \mathrm{OCH}_{2}\right), 5.00-5.20$ $\left(\mathrm{m}, 4 \mathrm{H} ; \mathrm{C}_{5} \mathrm{H}_{4}\right), 6.55$ (d, J=8.7 Hz, $\left.2 \mathrm{H} ; \mathrm{H}_{\text {arom }}\right), 6.77$ (d, J=8.7 Hz, $\left.2 \mathrm{H} ; \mathrm{H}_{\text {arom }}\right), 6.93$ (d, J=8.7 $\left.\mathrm{Hz}, 2 \mathrm{H} ; \mathrm{H}_{\text {arom }}\right), 7.00 \mathrm{ppm}\left(\mathrm{d}, J=8.7 \mathrm{~Hz}, 2 \mathrm{H} ; \mathrm{H}_{\text {arom }}\right) ;{ }^{13} \mathrm{C}$ NMR: $\delta=15.2\left(\mathrm{CH}_{3}\right), 29.0\left(\mathrm{CH}_{2}\right)$, $45.1\left(2 \mathrm{CH}_{3}\right), 58.0\left(\mathrm{CH}_{2}\right), 64.3\left(\mathrm{CH}_{2}\right), 82.5\left(2 \mathrm{CH}, \mathrm{C}_{5} \mathrm{H}_{4}\right), 85.5\left(2 \mathrm{CH}, \mathrm{C}_{5} \mathrm{H}_{4}\right), 109.9(1 \mathrm{C}$, $\left.\mathrm{C}_{5} \mathrm{H}_{4}\right), 114.0(2 \mathrm{CH}), 115.6(2 \mathrm{CH}), 129.7(\mathrm{C}), 130.2(2 \mathrm{CH}), 130.6(2 \mathrm{CH}), 134.2(\mathrm{C}), 136.1$ (C), 142.5 (C), 156.0 (C), 157.4 (C), 194.6 ppm (3 CO); MS (IE, $70 \mathrm{eV}): m / z: 645[M]^{+}$; elemental analysis calcd (\%) for $\mathrm{C}_{28} \mathrm{H}_{28} \mathrm{NO}_{5} \mathrm{Re}$ : C 52.16, H 4.38, N 2.17; found: C 52.04, H $4.55, \mathrm{~N} 2.29$. 
X- ray crystal structure determination of $(\boldsymbol{E})-\mathbf{7}$ a: A suitable crystal of $(\boldsymbol{E})-\mathbf{7}$ a was mounted on an Enraf-Nonius Mach- 3 diffractometer. Accurate cell dimensions and orientation matrices were obtained by least- squares refinement of 25 well- centred reflections. No significant variations were corrected from Lorentz and polarization effects. The structure was solved by direct methods (SHELXS) ${ }^{[45]}$ and refined by using the PC version of CRYSTALS. ${ }^{[46]}$ Scattering factors and corrections for anomalous absorption were taken from ref. [47]. All non- hydrogen atoms were anisotropically refined. Hydrogen atoms were introduced in calculated positions in the last refinements and they were allocated one overall isotropic thermal parameter. Main significant crystallographic data and collection details are summarized in Table 1.

CCDC- 233202 contains the supplementary crystallographic data for this paper. These data can be obtained free of charge via www.ccdc.cam.ac.uk/conts/retrieving.html (or from the Cambridge Crystallographic Data Centre, 12 Union Road, Cambridge CB2 1EZ, UK; fax: (+44) 1223-336033; or deposit@ccdc.cam.uk).

\section{Biochemical experiments:}

Materials: $17 \beta$ - Estradiol and $\mathrm{OH}-$ Tam $(Z+E)$ were obtained from Sigma-Aldrich (France); Ferrocene $\left[\left(\eta^{5}-\mathrm{C}_{5} \mathrm{H}_{5}\right)_{2} \mathrm{Fe}\right]$ was from Strem (Newburyport, MA, USA). Stock solutions $\left(1 \times 10^{-3} \mathrm{M}\right)$ of the compounds to be tested were prepared in ethanol and were kept at $-20{ }^{\circ} \mathrm{C}$ in the dark; under these conditions they are stable for at least 2 months. Serial dilutions in ethanol were prepared just prior to use. Dulbecco's modified eagle medium (DMEM) was purchased from Gibco BRL; fetal calf serum was from Dutscher, Brumath, France; glutamine, estradiol, and protamine sulfate were from Sigma. MCF7 and MDA- MB231 cells were from the Human Tumor Cell Bank.

Animal tissues: Sheep uteri weighing approximately $7 \mathrm{~g}$ were obtained from the slaughterhouse at Mantes- la- Jolie, France. They were immediately frozen and kept in liquid nitrogen prior to use.

\section{Determination of the relative binding affinity (RBA) of the compounds for ERa and} ERß: RBA values were measured on ER $\alpha$ from lamb uterine cytosol and on ER $\alpha$ and ER $\beta$ purchased from Pan Vera (Madison, WI, USA). Sheep uterine cytosol prepared in buffer A (0.05 M Tris- $\mathrm{HCl}, 0.25 \mathrm{M}$ sucrose, $0.1 \% \beta$ - mercaptoethanol, $\mathrm{pH} 7.4$ at $25^{\circ} \mathrm{C}$ ) as described in ref. [48] was used as a source of ER $\alpha$. For ER $\beta$, the solution containing 3500 
pmol $\mathrm{mL}^{-1}(10 \mu \mathrm{L})$ was added to buffer B $(16 \mathrm{~mL}, 10 \%$ glycerol, $50 \mathrm{mM}$ Bis- Tris- Propane, pH 9, $400 \mathrm{mM} \mathrm{KCl,} 2 \mathrm{mM}$ DTT, $1 \mathrm{mM}$ EDTA, 0.1\% BSA) in a silanised flask. Aliquots (200 $\mu \mathrm{L}$ ) of ER $\alpha$ in glass tubes or ER $\beta$ in polypropylene tubes were incubated for $3 \mathrm{~h}$ at $0{ }^{\circ} \mathrm{C}$ with [6,7- $\left.{ }^{3} \mathrm{H}\right]$ - estradiol $\left(2 \times 10^{-9} \mathrm{M}\right.$, specific activity $1.62 \mathrm{TBq} \mathrm{mmol}^{-1}$, NEN Life Science, Boston MA) in the presence of nine concentrations of the hormones to be tested. At the end of the incubation period, the free and bound fractions of the tracer were separated by protamine sulfate precipitation. The percentage reduction in binding of $\left[{ }^{3} \mathrm{H}\right]$ - estradiol $(Y)$ was calculated by using the logit transformation of $Y(\operatorname{logit} Y: \ln [y / 1-Y]$ versus the $\log$ of the mass of the competing steroid. The concentration of unlabeled steroid required to displace $50 \%$ of the bound $\left[{ }^{3} \mathrm{H}\right]$ - estradiol was calculated for each steroid tested, and the results expressed as RBA. The RBA value of estradiol is by definition equal to $100 \%$.

Measurement of octanol/water partition coefficient $\left(\log P_{0 / w}\right)$ of the compounds: The $\log P_{\mathrm{o} / \mathrm{w}}$ values of the compounds were determined by reversed- phase HPLC on a C- 8 column (nucleosil $5 \mathrm{C} 8$, from Macherey Nagel, France) according to the method previously described by Minick ${ }^{[49]}$ and Pomper. ${ }^{[50]}$ Measurement of the chromatographic capacity factors $\left(k^{\prime}\right)$ for each compound was done at various concentrations in the range 85-60\% methanol (containing $0.25 \%$ octanol) and an aqueous phase consisting of $0.15 \% n$ - decylamine in $0.02 \mathrm{M}$ MOPS (3- morpholinopropanesulfonic acid) $\mathrm{pH} 7.4$ buffer (prepared in 1- octanol- saturated water). These capacity factors $\left(k^{\prime}\right)$ are extrapolated to $100 \%$ of the aqueous component given the value of $k_{\mathrm{w}}^{\prime} \cdot \log P_{\mathrm{o} / \mathrm{w}}(y)$ is then obtained from the formula $\log P_{\mathrm{o} / \mathrm{w}}=0.13418+0.98452 \log k_{\mathrm{w}}^{\prime}$.

Culture conditions: Cells were maintained in monolayer in DMEM with phenol red (Gibco BRL) supplemented with 8-9\% fetal calf serum (Gibco BRL) and glutamine $2 \mathrm{mM}$ (Sigma) at $37^{\circ} \mathrm{C}$ in a $5 \% \mathrm{CO}_{2}$ air- humidified incubator. For proliferation assays, cells were plated in DMEM medium (1 mL) with phenol red, supplemented with $10 \%$ decomplemented and hormone- depleted fetal calf serum and $2 \mathrm{mM}$ glutamine and incubated. The following day (D0), $1 \mathrm{~mL}$ of the same medium containing the compounds to be tested was added to the plates (final volumes of alcohol: $0.1 \%$; 4 wells for each condition, one plate per day). After 3 days (D3) the incubation medium was removed and fresh medium containing the compounds was added. After 6 days (D6), the total protein content of the plate was analysed by methylene blue staining as follows: cell monolayers were fixed for $1 \mathrm{~h}$ in methanol, stained for $1 \mathrm{~h}$ with methylene blue $\left(1 \mathrm{mg} \mathrm{mL}^{-1}\right)$ in PBS, then washed thoroughly with water. $\mathrm{HCl}(1 \mathrm{~mL}, 0.1 \mathrm{M})$ 
was then added, and the absorbance of each well was measured at $620 \mathrm{~nm}$ with a Biorad spectrophotometer. The results are expressed as the percentage of proteins versus the control.

\section{Acknowledgements}

We thank A. Cordaville for technical assistance and B. McGlinchey for her help in translating the manuscript. Financial support from the Ministry of Research and the Centre National de la Recherche Scientifique is gratefully acknowledged.

[1] E. J. Feuer, L. M. Wun, C. C. Boring, W. D. Flanders, M. J. Timmel, T. Tong, J. Natl. Cancer Inst. 1993, 85, 892-897.

[2] V. C. Jordan, J. Med. Chem. 2003, 46, 883-908.

[3] V. C. Jordan, J. Med. Chem. 2003, 46, 1081-1111.

[4] K. Dhingra, Invest. New Drugs 1999 17, 285-311.

[5] M. J. Meegan, D. G. Lloyd, Curr. Med. Chem. 2003, 10, 181-210.

[6] A. M. Brzozowski, A. C. Pike, Z. Dauter, R. E. Hubbard, T. Bonn, O. Engstrom, L. Ohman, G. L. Greene, J.-A. Gustafsson, M. Carlquist, Nature 1997, 389, 753-758.

[7] A. C. Pike, A. M. Brzozowski, R. E. Hubbard, T. Bonn, A. G. Thorsell, O. Engstrom, J. Ljunggren, J.A. Gustafsson, M. Carlquist, E MBO J. 1999, 18, 4608-4618.

[8] A. C. Pike, A. M. Brzozowski, J. Walton, R. E. Hubbard, A. G. Thorsell, Y. L. Li, J.-A. Gustafsson, M. Carlquist, Structure (Camb) 2001, 9, 145-153.

[9] A. K. Shiau, D. Barstad, P. M. Loria, L. Cheng, P. J. Kushner, D. A. Agard, G. L. Greene, Cell 1998, 95, 927-937.

[10] D. M. Tanenbaum, Y. Wang, S. P. Williams, P. B. Sigler, Proc. Natl. Acad. Sci. USA 1998, 95, 59986003.

[11] J. A. Gustafsson, J. Endocrinol. 1999, 163, 379-383.

[12] K. Paech, P. Webb, G. G. Kuiper, S. Nilsson, J.-A. Gustafsson, P. J. Kushner, T. S. Scanlan, Science 1997, 277.

[13] P. de Cremoux, C. Tran-Perennou, C. Elie, E. Boudou, C. Barbaroux, M. Poupon, Y. De Rycke, B. Asselain, H. Magdelénat, Biochem. Pharmacol. 2002, 64, 507-515. 
[14] J. A. Gustafsson, Trends Pharmacol. Sci. 2003, 24, 479-485.

[15] V. Speirs, M. J. Kerin, Brit. J. Surgery 2000, 87, 405-409.

[16] V. Speirs, J. Pathol. 2002, 197, 143-147.

[17] S. Top, A. Vessières, G. Leclercq, J. Quivy, J. Tang, J. Vaissermann, M. Huché, G. Jaouen, Chem. Eur. J. 2003, 9, 5223-5236.

[18] E. A. Vladusic, A. E. Hornby, F. K. Guerra-Vladusic, R. Lupu, Cancer Res. 1998, 58, 210-214.

[19] C. Ferlini, G. Scambia, M. Marone, M. Distefano, C. Gaggini, G. Ferrandina, A. Fattorossi, G. Isola, P. Benedetti Panci, S. Mancuso, Brit. J. Cancer 1999, 79, 257-263.

[20] Technetium and Rhenium in Chemistry and Nuclear Medicine $n^{\circ} 3$, U. Mazzi (Ed.), Cortina International, Verona, 1990.

[21] Technetium and Rhenium in Chemistry and Nuclear Medicine $n^{\circ} 4$, U. Mazzi (Ed.), SG Editoriali, Padova, 1995.

[22] P. Bläuenstein, New J. Chem. 1990, 405-407.

[23] R. Alberto, Top. Curr. Chem. 1996, 176, 149-187.

[24] N. Metzler-Nolte, Angew. Chem. 2001, 113, 1072-1076; Angew. Chem. Int. Ed. 2001, 40, 1040-1043.

[25] F. Le Bideau, M. Salmain, S. Top, G. Jaouen, Chem. Eur. J. 2001, 7, 2289-2294.

[26] G. Jaouen, S. Top, A. Vessières, R. Alberto, J. Organomet. Chem. 2000, 600, 23-36.

[27] G. Jaouen, S. Top, A. Vessières, P. Pigeon, G. Leclercq, I. Laïos, Chem. Commun. 2001, 383-384.

[28] J. E. McMurry, Acc. Chem. Res. 1983, 16, 405.

[29] G. Precigoux, C. Courseille, S. Geoffre, M. Hospital, Acta Crystallogr. 1979, B35, 3070.

[30] D. W. Robertson, J. A. Katzenellenbogen, J. Org. Chem. 1982, 47, 2389.

[31] S. Top, B. Dauer, J. Vaissermann, G. Jaouen, J. Organomet. Chem. 1997, 541, 355-361.

[32] S. Top, H. El Hafa, A. Vessières, J. Quivy, J. Vaissermann, D. W. Huges, M. J. McGlinchey, J. P. Mornon, E. Thoreau, G. Jaouen, J. Am. Chem. Soc. 1995, 117, 8372-8380.

[33] Mac Spartam Pro, Wavefunction Co., Irvine CA 92612, USA.

[34] J. M. Cense, Phys. Theor. Chem. 1990, 71, 763-766.

[35] Weblab, Viewer Accelys, http://www.accelys.com. 
[36] R. N. Hanson, E. Napolitano, R. Fiaschi, J. Med. Chem. 1998, 41, 4686.

[37] G. Jaouen, S. Top, A. Vessières, G. Leclercq, J. Quivy, L. Jin, A. Croisy, C.R. Acad. Sci. Paris 2000, Série IIc, 89-93.

[38] A. A. Colletta, J. R. Benson, M. Baum, Breast Cancer Res. Treat. 1994, $31,5$.

[39] R. Alberto, R. Schibli, A. Egli, P. A. Schubiger, W. A. Hermann, G. Artus, V. Abram, T. A. Kaden, J. Organomet. Chem. 1995, 492, 217-224.

[40] R. Alberto, R. Schibli, A. Egli, U. Abram, S. Abram, T. A. Kaden, P. A. Schubiger, Polyhedron 1998, 17, 1133-1140.

[41] R. Alberto, R. Schibli, P. A. Schubiger, U. Abram, H. Hsbener, H. Berke, T. A. Kaden, Chem. Commun. 1996, 1291-1292.

[42] J. Wald, R. Alberto, K. Ortner, L. Candreia, Angew. Chem. 2001, 113, 3152-3156; Angew. Chem. Int. Ed. 2001, 40, 3062-3066.

[43] S. Top, S. Masi, G. Jaouen, Eur. J. Inorg. Chem. 2002, 1848-1853.

[44] S. Masi, S. Top, L. Boubekeur, G. Jaouen, S. Mundwiler, B. Spingler, R. Alberto, Eur. J. Inorg. Chem. 2004, 2013-2017.

[45] G. M. Sheldrick, SHELXS86, Program for the solution of crystal structures. Univ. Gottingen, Germany.

[46] D. J. Watkins, C. K. Prout, J. R. Carruthers, P. W. Bettridge, CRYSTALS Issue 10 1996, Chemical Crystallography Laboratory, Oxford, UK.

[47] D. T. Cromer, International Tables for X-ray Crystallography, Kynoch Press, Birmingham, UK, 1974, Vol. IV.

[48] A. Vessières, S. Top, A. A. Ismail, I. S. Butler, M. Loüer, G. Jaouen, Biochemistry 1988, 27, 66596666.

[49] D. J. Minick, J. H. Frenz, M. A. Patrick, D. A. Brent, J. Med. Chem. 1988, 31, 1923-1933.

[50] M. G. Pomper, H. VanBrocklin, A. M. Thieme, R. D. Thomas, D. O. Kiese-wetter, K. E. Carlson, C. J. Mathias, M. J. Welch, J. A. Katzenellenbogen, J. Med. Chem. 1990, 33, 3143-3155. 


\section{Supporting Information}

\section{Experimental Section}

General Data. Starting materials were synthesized using standard Schlenk techniques, under an argon atmosphere. Anhydrous THF and diethyl ether were distilled from sodium/benzophenone. Thin layer chromatography was performed on silica gel 60 GF254. FT-IR spectra were recorded on a BOMEM Michelson-100 spectrometer as a $\mathrm{KBr}$ plate. ${ }^{1} \mathrm{H}$ and ${ }^{13} \mathrm{C}$ NMR spectra were acquired on Bruker 200 and Bruker 400 spectrometers by using $\mathrm{CDCl}_{3}$ as a solvent. Mass spectrometry was performed on a Nermag R 10-10C spectrometer. Melting points were measured with a Kofler device. Elemental analyses were performed by the Regional Microanalysis Department of Université Pierre et Marie Curie. 4Halogenoalkoxyphenyl-4'-hydroxyphenyl ketones 4a-e : In a Schlenk tube filled with argon was introduced potassium hydride (5.70 $\mathrm{g}$ of $35 \%$ dispersion in oil, $50 \mathrm{mmol}$ ). The mixture was washed three times with petroleum ether, then the rest of the petroleum ether was evaporated under reduced pressure for 10 minutes. Dry THF $(100 \mathrm{~mL})$ was added. A solution of 4,4'-dihydroxybenzophenone (10.7 g, $50 \mathrm{mmol})$ in $N, N$-dimethylformamide (200 ml) was carefully added with a syringe. The yellow mixture was heated for 10 minutes, then was cooled. The corresponding dihaloalkane $(250 \mathrm{mmol})$ was rapidly added, and then the mixture was heated again at gentle reflux overnight. The solution was cooled, the solvent was removed under reduced pressure. The residue was chromatographed with silica gel column by using dichloromethane/acetone $95 / 5$ as eluent. Recrystallization from dichloromethane furnished pure ketone 4a-e.

4a : Yield 12\%; mp $141^{\circ} \mathrm{C}$. IR: $3183(\mathrm{OH}), 1600(\mathrm{C}=\mathrm{O}) \mathrm{cm}^{-1} .{ }^{1} \mathrm{H}$ NMR: $\delta 3.68(\mathrm{t}, \mathrm{J}=6.2 \mathrm{~Hz}$, $\left.2 \mathrm{H}, \mathrm{CH}_{2}\right), 4.38\left(\mathrm{t}, \mathrm{J}=6.2 \mathrm{~Hz}, 2 \mathrm{H}, \mathrm{CH}_{2}\right), 6.93\left(\mathrm{~d}, \mathrm{~J}=8.9 \mathrm{~Hz}, 2 \mathrm{H}, \mathrm{H}_{\text {arom }}\right), 6.98(\mathrm{~d}, \mathrm{~J}=8.8 \mathrm{~Hz}$, $\left.2 \mathrm{H}, \mathrm{H}_{\text {arom }}\right), 7.05$ (s, 1H, OH), 7.74 (d, J = 8.8 Hz, 2H, $\left.\mathrm{H}_{\text {arom }}\right), 7.79$ (d, J = 8.9 Hz, 2H, $\mathrm{H}_{\text {arom }}$ ). ${ }^{13} \mathrm{C}$ NMR: $\delta 28.5\left(\mathrm{CH}_{2}\right), 67.8\left(\mathrm{CH}_{2}\right), 114.1(2 \mathrm{CH}), 115.1(2 \mathrm{CH}), 130.0(\mathrm{C}), 131.1(\mathrm{C}), 132.3$ (2 CH), 132.6 (2 CH), 160.1 (C), 161.4 (C), 195.2 (CO). MS (IE, 70 eV) m/z: $320[\mathrm{M}]^{+}$.

4b : Yield 37\%; mp $147^{\circ} \mathrm{C}$. IR: $3146(\mathrm{OH}), 1600(\mathrm{C}=\mathrm{O}) \mathrm{cm}^{-1} .{ }^{1} \mathrm{H}$ NMR: $\delta 2.35$ (quintuplet, J $\left.=6.1 \mathrm{~Hz}, 2 \mathrm{H}, \mathrm{CH}_{2}\right), 3.62\left(\mathrm{t}, \mathrm{J}=6.1 \mathrm{~Hz}, 2 \mathrm{H}, \mathrm{CH}_{2}\right), 4.19\left(\mathrm{t}, \mathrm{J}=6.1 \mathrm{~Hz}, 2 \mathrm{H}, \mathrm{CH}_{2}\right), 6.98(\mathrm{~d}, \mathrm{~J}=$ $\left.8.8 \mathrm{~Hz}, 2 \mathrm{H}, \mathrm{H}_{\text {arom }}\right), 6.99\left(\mathrm{~d}, \mathrm{~J}=8.7 \mathrm{~Hz}, 2 \mathrm{H}, \mathrm{H}_{\text {arom }}\right), 7.75\left(\mathrm{~d}, \mathrm{~J}=8.7 \mathrm{~Hz}, 2 \mathrm{H}, \mathrm{H}_{\text {arom }}\right), 7.81$ (d, J = $\left.8.8 \mathrm{~Hz}, 2 \mathrm{H}, \mathrm{H}_{\text {arom }}\right), 8.76(\mathrm{~s}, 1 \mathrm{H}, \mathrm{OH}) .{ }^{13} \mathrm{C} \mathrm{NMR}: \delta 29.7\left(\mathrm{CH}_{2}\right), 32.0\left(\mathrm{CH}_{2}\right), 65.5\left(\mathrm{CH}_{2}\right), 1143.0$ 
(2 CH), 115.3 (2 CH), $129.5(\mathrm{C}), 130.5(\mathrm{C}), 132.4$ (2 CH), $132.8(2 \mathrm{CH}), 161.0(\mathrm{C}), 162.2$ (C), 195.9 (CO); MS (IE, 70 eV) m/z: $334[\mathrm{M}]^{+}$.

4c : Yield 35\%; mp 102 ${ }^{\circ} \mathrm{C}$. IR: $3130(\mathrm{OH}), 1603(\mathrm{C}=\mathrm{O}) \mathrm{cm}^{-1} .{ }^{1} \mathrm{H}$ NMR: $\delta$ 1.88-2.25 (m, 4H, $\left.\mathrm{CH}_{2}-\mathrm{CH}_{2}\right), 3.51\left(\mathrm{t}, \mathrm{J}=6.0 \mathrm{~Hz}, 2 \mathrm{H}, \mathrm{CH}_{2}\right), 4.08\left(\mathrm{t}, \mathrm{J}=6.0 \mathrm{~Hz}, 2 \mathrm{H}, \mathrm{CH}_{2}\right), 6.94(\mathrm{~d}, \mathrm{~J}=8.4 \mathrm{~Hz}$, $\left.4 \mathrm{H}, \mathrm{H}_{\text {arom }}\right), 7.73$ (d, J = 8.4 Hz, 2H, $\left.\mathrm{H}_{\text {arom }}\right), 7.78$ (d, J = $\left.8.4 \mathrm{~Hz}, 2 \mathrm{H}, \mathrm{H}_{\text {arom }}\right), 8.05$ (s, 1H, OH); ${ }^{13} \mathrm{C}$ NMR: $\delta 27.7\left(\mathrm{CH}_{2}\right), 29.3\left(\mathrm{CH}_{2}\right), 33.2\left(\mathrm{CH}_{2}\right), 67.0\left(\mathrm{CH}_{2}\right), 113.8(2 \mathrm{CH}), 115.1(2 \mathrm{CH})$, 129.8 (C), 130.7 (C), 132.2 (2 CH), 132.5 (2 CH), 160.6 (C), 162.0 (C), 194.9 (CO).

4d : Yield 40\%; oil. IR: $3460(\mathrm{OH}), 1602(\mathrm{C}=\mathrm{O}) \mathrm{cm}^{-1} .{ }^{1} \mathrm{H}$ NMR: $\delta$ 1.54-2.08 (m, 6H, $\mathrm{CH}_{2}-$ $\left.\mathrm{CH}_{2}-\mathrm{CH}_{2}\right), 3.46\left(\mathrm{t}, \mathrm{J}=6.6 \mathrm{~Hz}, 2 \mathrm{H}, \mathrm{CH}_{2}\right), 4.06\left(\mathrm{t}, \mathrm{J}=6.1 \mathrm{~Hz}, 2 \mathrm{H}, \mathrm{CH}_{2}\right), 4.75(\mathrm{~s}, 1 \mathrm{H}, \mathrm{OH}), 6.92$ $\left(\mathrm{d}, \mathrm{J}=8.4 \mathrm{~Hz}, 2 \mathrm{H}, \mathrm{H}_{\text {arom }}\right), 6.95\left(\mathrm{~d}, \mathrm{~J}=8.4 \mathrm{~Hz}, 2 \mathrm{H}, \mathrm{H}_{\text {arom }}\right), 7.73\left(\mathrm{~d}, \mathrm{~J}=8.4 \mathrm{~Hz}, 2 \mathrm{H}, \mathrm{H}_{\text {arom }}\right), 7.78$ $\left(\mathrm{d}, \mathrm{J}=8.4 \mathrm{~Hz}, 2 \mathrm{H}, \mathrm{H}_{\text {arom}}\right) ;{ }^{13} \mathrm{C} \mathrm{NMR}: \delta 24.5\left(\mathrm{CH}_{2}\right), 28.0\left(\mathrm{CH}_{2}\right), 32.1\left(\mathrm{CH}_{2}\right), 33.2\left(\mathrm{CH}_{2}\right), 67.6$ $\left(\mathrm{CH}_{2}\right), 113.7(2 \mathrm{CH}), 115.0(2 \mathrm{CH}), 129.7(\mathrm{C}), 130.1(\mathrm{C}), 132.2(2 \mathrm{CH}), 132.4(2 \mathrm{CH}), 160.2$ (C), 162.2 (C), 195.3 (CO); MS (IE, $70 \mathrm{eV}) \mathrm{m} / \mathrm{z}: 362[\mathrm{M}]^{+}$.

4e : Yield 37\%; mp 97 C. IR: $3374(\mathrm{OH}), 1598(\mathrm{C}=\mathrm{O}) \mathrm{cm}^{-1} ;{ }^{1} \mathrm{H}$ NMR: $\delta$ 1.29-1.95 (m, 12H, $\left.\left(\mathrm{CH}_{2}\right)_{6^{-}}\right), 3.55\left(\mathrm{t}, \mathrm{J}=6.6 \mathrm{~Hz}, 2 \mathrm{H}, \mathrm{CH}_{2}\right), 4.04\left(\mathrm{t}, \mathrm{J}=6.4 \mathrm{~Hz}, 2 \mathrm{H}, \mathrm{CH}_{2}\right), 6.30(\mathrm{~s}, 1 \mathrm{H}, \mathrm{OH}), 6.92$ $\left(\mathrm{d}, \mathrm{J}=8.9 \mathrm{~Hz}, 2 \mathrm{H}, \mathrm{H}_{\text {arom }}\right), 6.95\left(\mathrm{~d}, \mathrm{~J}=8.9 \mathrm{~Hz}, 2 \mathrm{H}, \mathrm{H}_{\text {arom }}\right), 7.74\left(\mathrm{~d}, \mathrm{~J}=8.9 \mathrm{~Hz}, 2 \mathrm{H}, \mathrm{H}_{\text {arom }}\right), 7.78$ $\left(\mathrm{d}, \mathrm{J}=8.9 \mathrm{~Hz}, 2 \mathrm{H}, \mathrm{H}_{\text {arom }}\right) ;{ }^{13} \mathrm{C} \mathrm{NMR}: \delta 25.8\left(\mathrm{CH}_{2}\right), 26.7\left(\mathrm{CH}_{2}\right), 28.7\left(\mathrm{CH}_{2}\right), 28.9\left(\mathrm{CH}_{2}\right), 29.0$ $\left(\mathrm{CH}_{2}\right), 32.5\left(\mathrm{CH}_{2}\right), 45.0\left(\mathrm{CH}_{2}\right), 68.1\left(\mathrm{CH}_{2}\right), 113.9(2 \mathrm{CH}), 115.0(2 \mathrm{CH}), 130.2(\mathrm{C}), 130.4(\mathrm{C})$, 132.3 (2 CH), 132.5 (2 CH), 159.8 (C), 162.5 (C), 195.1 (CO); MS (IE, 70 eV) m/z: 360 $[\mathrm{M}]^{+}$.

Alkenes 6a-e : Titanium tetrachloride $(2 \mathrm{ml}, 18 \mathrm{mmol})$ was added dropwise to a suspension of zinc powder $(2.34 \mathrm{~g}, 36 \mathrm{mmol})$ in $60 \mathrm{~mL}$ of $\mathrm{THF}$ at $0^{\circ} \mathrm{C}$. The mixture obtained was heated at reflux for $2 \mathrm{~h}$ and then allowed to cool to room temperature. A second solution was prepared by dissolving 4-haloalkoxy-4'-hydroxybenzophenone 4a-e (6 mmol) and ketone 5 (2.35 g, 6 $\mathrm{mmol}$ ) in $30 \mathrm{~mL}$ of THF. This latter solution was added dropwise to the first solution and then the resulting mixture was heated at reflux for $2 \mathrm{~h}$. After cooling to room temperature, the mixture was stirred with water and dichloromethane. The mixture was acidified with dilute hydrochloric acid, filtered on celite and the organic layer was dried over magnesium sulfate. After concentration under reduced pressure, the crude product was chromatographed on silica gel plates with dichloromethane as eluent to give pure oily $(Z+E)$ mixture of $6 \mathbf{a - e}$. 
6a : Yield 64\%. IR: $3422(\mathrm{OH}), 2018$ and $1920(\mathrm{C}=\mathrm{O}) \mathrm{cm}^{-1}$. MS (IE, $\left.70 \mathrm{eV}\right) \mathrm{m} / \mathrm{z}: 680[\mathrm{M}]^{+}$, $596[\mathrm{M}-3 \mathrm{CO}]^{+}$. Major isomer: ${ }^{1} \mathrm{H}$ NMR: $\delta 1.06\left(\mathrm{t}, \mathrm{J}=7.5 \mathrm{~Hz}, 3 \mathrm{H}, \mathrm{CH}_{3}\right), 2.26(\mathrm{q}, \mathrm{J}=7.5 \mathrm{~Hz}$, $\left.2 \mathrm{H}, \mathrm{CH}_{2}\right), 3.63\left(\mathrm{t}, \mathrm{J}=6.2 \mathrm{~Hz}, 2 \mathrm{H}, \mathrm{CH}_{2}\right), 4.28\left(\mathrm{t}, \mathrm{J}=6.2 \mathrm{~Hz}, 2 \mathrm{H}, \mathrm{CH}_{2}\right), 5.01-5.16(\mathrm{~m}, 4 \mathrm{H}$, $\left.\mathrm{C}_{5} \mathrm{H}_{4}\right), 6.68-7.15$ (m, 8H, Harom $) .{ }^{13} \mathrm{C}$ NMR: $\delta 15.2\left(\mathrm{CH}_{3}\right), 29.1\left(\mathrm{CH}_{2}\right), 30.8\left(\mathrm{CH}_{2}\right), 67.7\left(\mathrm{CH}_{2}\right)$, $82.7\left(2 \mathrm{CH}, \mathrm{C}_{5} \mathrm{H}_{4}\right), 85.6\left(2 \mathrm{CH}, \mathrm{C}_{5} \mathrm{H}_{4}\right), 108.9\left(1 \mathrm{C}, \mathrm{C}_{5} \mathrm{H}_{4}\right), 114.4(2 \mathrm{CH}), 115.5(2 \mathrm{CH}), 130.0$ (2 CH), 130.4 (C), 130.6 (2 CH), 135.5 (C), 136.3 (C), 141.9 (C), 154.9 (C), 156.8 (C), 194.6 (3 CO). Minor isomer: ${ }^{1} \mathrm{H}$ NMR: $\delta 1.06\left(\mathrm{t}, \mathrm{J}=7.5 \mathrm{~Hz}, 3 \mathrm{H}, \mathrm{CH}_{3}\right), 2.27(\mathrm{q}, \mathrm{J}=7.5 \mathrm{~Hz}, 2 \mathrm{H}$, $\left.\mathrm{CH}_{2}\right), 3.63\left(\mathrm{t}, \mathrm{J}=6.2 \mathrm{~Hz}, 2 \mathrm{H}, \mathrm{CH}_{2}\right), 4.26\left(\mathrm{t}, \mathrm{J}=6.2 \mathrm{~Hz}, 2 \mathrm{H}, \mathrm{CH}_{2}\right), 5.01-5.16\left(\mathrm{~m}, 4 \mathrm{H}, \mathrm{C}_{5} \mathrm{H}_{4}\right)$, 6.68-7.15 (m, 8H, Harom $).{ }^{13} \mathrm{C}$ NMR: $\delta 15.2\left(\mathrm{CH}_{3}\right), 29.1\left(\mathrm{CH}_{2}\right), 30.8\left(\mathrm{CH}_{2}\right), 67.7\left(\mathrm{CH}_{2}\right), 82.7$ (2 $\left.\mathrm{CH}, \mathrm{C}_{5} \mathrm{H}_{4}\right), 85.6\left(2 \mathrm{CH}, \mathrm{C}_{5} \mathrm{H}_{4}\right), 108.9\left(1 \mathrm{C}, \mathrm{C}_{5} \mathrm{H}_{4}\right), 114.7(2 \mathrm{CH}), 115.2(2 \mathrm{CH}), 130.0$ (2 $\mathrm{CH}), 130.4(\mathrm{C}), 130.6$ (2 CH), 135.2 (C), 136.6 (C), 141.9 (C), 154.7 (C), 156.9 (C), 194.6 (3 $\mathrm{CO})$.

6b : Yield 68\%. IR: $3431(\mathrm{OH}), 2018$ and $1918(\mathrm{C}=\mathrm{O}) \mathrm{cm}^{-1}$. MS (IE, $\left.70 \mathrm{eV}\right) \mathrm{m} / \mathrm{e}: 694[\mathrm{M}]^{+}$, $610[\mathrm{M}-3 \mathrm{CO}]^{+}$. Major isomer: ${ }^{1} \mathrm{H}$ NMR: $\delta 1.07$ (t, J = 7.4 Hz, 3H, $\left.\mathrm{CH}_{3}\right), 2.23-2.40(\mathrm{~m}, 4 \mathrm{H}, 2$ $\left.\mathrm{CH}_{2}\right), 3.60\left(\mathrm{t}, \mathrm{J}=6.4 \mathrm{~Hz}, 2 \mathrm{H}, \mathrm{CH}_{2}\right), 4.09\left(\mathrm{t}, \mathrm{J}=5.5 \mathrm{~Hz}, 2 \mathrm{H}, \mathrm{CH}_{2}\right), 5.01-5.16\left(\mathrm{~m}, 4 \mathrm{H}, \mathrm{C}_{5} \mathrm{H}_{4}\right)$, $6.45(\mathrm{~s}, 1 \mathrm{H}, \mathrm{OH}), 6.69-6.91\left(\mathrm{~m}, 4 \mathrm{H}, \mathrm{H}_{\text {arom }}\right), 6.91-7.16\left(\mathrm{~m}, 4 \mathrm{H}, \mathrm{H}_{\text {arom }}\right) .{ }^{13} \mathrm{C} \mathrm{NMR}: \delta 15.2\left(\mathrm{CH}_{3}\right)$, $28.9\left(\mathrm{CH}_{2}\right), 30.0\left(\mathrm{CH}_{2}\right), 32.3\left(\mathrm{CH}_{2}\right), 65.2\left(\mathrm{CH}_{2}\right), 82.7\left(2 \mathrm{CH}, \mathrm{C}_{5} \mathrm{H}_{4}\right), 85.6\left(2 \mathrm{CH}, \mathrm{C}_{5} \mathrm{H}_{4}\right), 109.0$ $\left(1 \mathrm{C}, \mathrm{C}_{5} \mathrm{H}_{4}\right), 114.2(2 \mathrm{CH}), 115.5(2 \mathrm{CH}), 130.0(2 \mathrm{CH}), 130.2(\mathrm{C}), 130.6(2 \mathrm{CH}), 135.5(\mathrm{C})$, 135.8 (C), 142.1 (C), 155.0 (C), 157.4 (C), 194.7 (3 CO). Minor isomer: ${ }^{1} \mathrm{H}$ NMR: $\delta 1.07$ (t, J $\left.=7.4 \mathrm{~Hz}, 3 \mathrm{H}, \mathrm{CH}_{3}\right), 2.23-2.40\left(\mathrm{~m}, 4 \mathrm{H}, 2 \mathrm{CH}_{2}\right), 3.60\left(\mathrm{t}, \mathrm{J}=6.4 \mathrm{~Hz}, 2 \mathrm{H}, \mathrm{CH}_{2}\right), 4.09(\mathrm{t}, \mathrm{J}=5.5$ $\mathrm{Hz}, 2 \mathrm{H}, \mathrm{CH}_{2}$ ), 5.01-5.16 (m, 4H, $\left.\mathrm{C}_{5} \mathrm{H}_{4}\right), 6.45$ (s, 1H, OH), 6.69-6.91 (m, 4H, $\mathrm{H}_{\text {arom}}$ ), 6.91-7.16 (m, 4H, $\left.\mathrm{H}_{\text {arom }}\right) .{ }^{13} \mathrm{C}$ NMR: $\delta 15.2\left(\mathrm{CH}_{3}\right), 28.9\left(\mathrm{CH}_{2}\right), 30.0\left(\mathrm{CH}_{2}\right), 32.3\left(\mathrm{CH}_{2}\right), 65.2\left(\mathrm{CH}_{2}\right), 82.7$ (2 $\left.\mathrm{CH}, \mathrm{C}_{5} \mathrm{H}_{4}\right), 85.6\left(2 \mathrm{CH}, \mathrm{C}_{5} \mathrm{H}_{4}\right), 109.1\left(1 \mathrm{C}, \mathrm{C}_{5} \mathrm{H}_{4}\right), 114.4(2 \mathrm{CH}), 115.2(2 \mathrm{CH}), 130.1$ (2 $\mathrm{CH}), 130.2$ (C), 130.5 (2 CH), 135.2 (C), 136.1 (C), 142.1 (C), 154.8 (C), 157.5 (C), 194.7 (3 $\mathrm{CO})$.

6c : Yield 62\%; IR: $3438(\mathrm{OH}), 2018$ and $1918(\mathrm{C}=\mathrm{O}) \mathrm{cm}^{-1}$. MS (IE, $\left.70 \mathrm{eV}\right) \mathrm{m} / \mathrm{z}: 708[\mathrm{M}]^{+}$, $624[\mathrm{M}-3 \mathrm{CO}]^{+}$. Major isomer: ${ }^{1} \mathrm{H}$ NMR: $\delta 1.07\left(\mathrm{t}, \mathrm{J}=7.6 \mathrm{~Hz}, 3 \mathrm{H}, \mathrm{CH}_{3}\right), 1.80-2.18(\mathrm{~m}, 4 \mathrm{H}$, $\left.\left(\mathrm{CH}_{2}\right)_{2}\right), 2.28$ (q, J = 7.6 Hz, 2H, $\left.\mathrm{CH}_{2}\right), 3.50\left(\mathrm{t}, \mathrm{J}=6.4 \mathrm{~Hz}, 2 \mathrm{H}, \mathrm{CH}_{2}\right), 3.99(\mathrm{t}, \mathrm{J}=6.4 \mathrm{~Hz}, 2 \mathrm{H}$, $\left.\mathrm{CH}_{2}\right)$, 5.01-5.16 (m, 4H, $\left.\mathrm{C}_{5} \mathrm{H}_{4}\right), 6.67-6.90\left(\mathrm{~m}, 4 \mathrm{H}, \mathrm{H}_{\text {arom }}\right), 6.90-7.14\left(\mathrm{~m}, 4 \mathrm{H}, \mathrm{H}_{\text {arom }}\right) .{ }^{13} \mathrm{C} \mathrm{NMR}$ : ठ $15.2\left(\mathrm{CH}_{3}\right), 27.8\left(\mathrm{CH}_{2}\right), 29.0\left(\mathrm{CH}_{2}\right), 29.4\left(\mathrm{CH}_{2}\right), 33.4\left(\mathrm{CH}_{2}\right), 67.7\left(\mathrm{CH}_{2}\right), 82.7\left(2 \mathrm{CH}, \mathrm{C}_{5} \mathrm{H}_{4}\right)$, $85.6\left(2 \mathrm{CH}, \mathrm{C}_{5} \mathrm{H}_{4}\right), 109.0\left(1 \mathrm{C}, \mathrm{C}_{5} \mathrm{H}_{4}\right), 114.2(2 \mathrm{CH}), 115.4(2 \mathrm{CH}), 129.9(2 \mathrm{CH}), 130.3(\mathrm{C})$, 130.7 (2 CH), 135.5 (C), 135.9 (C), 141.9 (C), 154.5 (C), 157.6 (C), 194.6 (3 CO). Minor 
isomer: ${ }^{1} \mathrm{H}$ NMR: $\delta 1.07\left(\mathrm{t}, \mathrm{J}=7.6 \mathrm{~Hz}, 3 \mathrm{H}, \mathrm{CH}_{3}\right), 1.80-2.18\left(\mathrm{~m}, 4 \mathrm{H},\left(\mathrm{CH}_{2}\right)_{2}\right), 2.28(\mathrm{q}, \mathrm{J}=7.6$ $\left.\mathrm{Hz}, 2 \mathrm{H}, \mathrm{CH}_{2}\right), 3.50$ (t, J = 6.4 Hz, 2H, $\left.\mathrm{CH}_{2}\right), 3.99$ (t, J = 6.4 Hz, 2H, $\left.\mathrm{CH}_{2}\right), 5.01-5.16$ (m, 4H, $\left.\mathrm{C}_{5} \mathrm{H}_{4}\right), 6.67-6.90\left(\mathrm{~m}, 4 \mathrm{H}, \mathrm{H}_{\text {arom }}\right), 6.90-7.14\left(\mathrm{~m}, 4 \mathrm{H}, \mathrm{H}_{\text {arom }}\right) .{ }^{13} \mathrm{C} \mathrm{NMR}: \delta 15.2\left(\mathrm{CH}_{3}\right), 27.8$ $\left(\mathrm{CH}_{2}\right), 29.0\left(\mathrm{CH}_{2}\right), 29.4\left(\mathrm{CH}_{2}\right), 33.4\left(\mathrm{CH}_{2}\right), 67.7\left(\mathrm{CH}_{2}\right), 82.7\left(2 \mathrm{CH}, \mathrm{C}_{5} \mathrm{H}_{4}\right), 85.6(2 \mathrm{CH}$, $\left.\mathrm{C}_{5} \mathrm{H}_{4}\right), 109.0\left(1 \mathrm{C}, \mathrm{C}_{5} \mathrm{H}_{4}\right), 114.4(2 \mathrm{CH}), 115.2(2 \mathrm{CH}), 130.1(2 \mathrm{CH}), 130.3(\mathrm{C}), 130.5(2 \mathrm{CH})$, 135.6 (C), 135.8 (C), 141.9 (C), 154.4 (C), 157.7 (C), 194.6 (3 CO).

6d : Yield 70\%. IR: $3422(\mathrm{OH}), 2018$ and $1919(\mathrm{C}=\mathrm{O}) \mathrm{cm}^{-1}$. MS (IE, $\left.70 \mathrm{eV}\right) \mathrm{m} / \mathrm{z}: 722\left[\mathrm{M}^{+}\right]$, $638\left[\mathrm{M}^{+}-3 \mathrm{CO}\right.$ ]. Major isomer: ${ }^{1} \mathrm{H}$ NMR: $\delta 1.06\left(\mathrm{t}, \mathrm{J}=7.5 \mathrm{~Hz}, 3 \mathrm{H}, \mathrm{CH}_{3}\right), 1.50-2.07(\mathrm{~m}, 6 \mathrm{H}$, $\left.\left(\mathrm{CH}_{2}\right)_{3}\right), 2.26\left(\mathrm{q}, \mathrm{J}=7.5 \mathrm{~Hz}, 2 \mathrm{H}, \mathrm{CH}_{2}\right), 3.44\left(\mathrm{t}, \mathrm{J}=6.8 \mathrm{~Hz}, 2 \mathrm{H}, \mathrm{CH}_{2}\right), 3.96(\mathrm{t}, \mathrm{J}=6.2 \mathrm{~Hz}, 2 \mathrm{H}$, $\left.\mathrm{CH}_{2}\right)$, 5.01-5.16 (m, 4H, $\left.\mathrm{C}_{5} \mathrm{H}_{4}\right), 6.67-6.90\left(\mathrm{~m}, 4 \mathrm{H}, \mathrm{H}_{\text {arom }}\right), 6.90-7.14\left(\mathrm{~m}, 4 \mathrm{H}, \mathrm{H}_{\text {arom }}\right) .{ }^{13} \mathrm{C} \mathrm{NMR}$ : 反 $15.2\left(\mathrm{CH}_{3}\right), 24.7\left(\mathrm{CH}_{2}\right), 28.3\left(\mathrm{CH}_{2}\right), 29.0\left(\mathrm{CH}_{2}\right), 32.3\left(\mathrm{CH}_{2}\right), 33.5\left(\mathrm{CH}_{2}\right), 67.4\left(\mathrm{CH}_{2}\right), 82.6(2$ $\left.\mathrm{CH}, \mathrm{C}_{5} \mathrm{H}_{4}\right), 85.6\left(2 \mathrm{CH}, \mathrm{C}_{5} \mathrm{H}_{4}\right), 109.1\left(1 \mathrm{C}, \mathrm{C}_{5} \mathrm{H}_{4}\right), 114.1(2 \mathrm{CH}), 115.4(2 \mathrm{CH}), 129.9(2 \mathrm{CH})$, 130.2 (C), 130.7 (2 CH), 135.4 (C), 135.7 (C), 142.1 (C), 154.7 (C), 157.7 (C), 194.6 (3 CO). Minor isomer: ${ }^{1} \mathrm{H}$ NMR: $\delta 1.06\left(\mathrm{t}, \mathrm{J}=7.5 \mathrm{~Hz}, 3 \mathrm{H}, \mathrm{CH}_{3}\right), 1.50-2.07\left(\mathrm{~m}, 6 \mathrm{H},\left(\mathrm{CH}_{2}\right)_{3}\right), 2.26(\mathrm{q}, \mathrm{J}$ $\left.=7.5 \mathrm{~Hz}, 2 \mathrm{H}, \mathrm{CH}_{2}\right), 3.44\left(\mathrm{t}, \mathrm{J}=6.8 \mathrm{~Hz}, 2 \mathrm{H}, \mathrm{CH}_{2}\right), 3.95\left(\mathrm{t}, \mathrm{J}=6.2 \mathrm{~Hz}, 2 \mathrm{H}, \mathrm{CH}_{2}\right), 5.01-5.16(\mathrm{~m}$, $\left.4 \mathrm{H}, \mathrm{C}_{5} \mathrm{H}_{4}\right), 6.67-6.90\left(\mathrm{~m}, 4 \mathrm{H}, \mathrm{H}_{\text {arom }}\right), 6.90-7.14\left(\mathrm{~m}, 4 \mathrm{H}, \mathrm{H}_{\text {arom }}\right) .{ }^{13} \mathrm{C} \mathrm{NMR}: \delta 15.2\left(\mathrm{CH}_{3}\right), 24.7$ $\left(\mathrm{CH}_{2}\right), 28.3\left(\mathrm{CH}_{2}\right), 29.0\left(\mathrm{CH}_{2}\right), 32.3\left(\mathrm{CH}_{2}\right), 33.5\left(\mathrm{CH}_{2}\right), 67.4\left(\mathrm{CH}_{2}\right), 82.6\left(2 \mathrm{CH}, \mathrm{C}_{5} \mathrm{H}_{4}\right), 85.5$ $\left(2 \mathrm{CH}, \mathrm{C}_{5} \mathrm{H}_{4}\right), 109.1\left(1 \mathrm{C}, \mathrm{C}_{5} \mathrm{H}_{4}\right), 114.4(2 \mathrm{CH}), 115.1(2 \mathrm{CH}), 130.1(2 \mathrm{CH}), 130.2(\mathrm{C}), 130.5$ (2 CH), 135.4 (C), 135.7 (C), $142.1(\mathrm{C}), 154.6(\mathrm{C}), 157.8$ (C), 194.6 (3 CO).

6e : Yield 68\%; IR: $3412(\mathrm{OH}), 2019$ and $1913(\mathrm{C}=\mathrm{O}) \mathrm{cm}^{-1}$. MS (IE, $\left.70 \mathrm{eV}\right) \mathrm{m} / \mathrm{z}: 720\left[\mathrm{M}^{+\cdot}\right]$, 636 [M+3CO]. Major isomer: ${ }^{1} \mathrm{H}$ NMR: $\delta 1.07\left(\mathrm{t}, \mathrm{J}=7.5 \mathrm{~Hz}, 3 \mathrm{H}, \mathrm{CH}_{3}\right), 1.23-1.90(\mathrm{~m}, 12 \mathrm{H}$, $\left.\left(\mathrm{CH}_{2}\right)_{6^{-}}\right), 2.27\left(\mathrm{q}, \mathrm{J}=7.5 \mathrm{~Hz}, 2 \mathrm{H}, \mathrm{CH}_{2}\right), 3.55\left(\mathrm{t}, \mathrm{J}=6.6 \mathrm{~Hz}, 2 \mathrm{H}, \mathrm{CH}_{2}\right), 3.95(\mathrm{t}, \mathrm{J}=6.4 \mathrm{~Hz}, 2 \mathrm{H}$, $\left.\mathrm{CH}_{2}\right)$, 5.01-5.16 (m, 4H, $\left.\mathrm{C}_{5} \mathrm{H}_{4}\right), 6.68-6.90\left(\mathrm{~m}, 4 \mathrm{H}, \mathrm{H}_{\text {arom }}\right), 6.90-7.13\left(\mathrm{~m}, 4 \mathrm{H}, \mathrm{H}_{\text {arom }}\right) .{ }^{13} \mathrm{C} \mathrm{NMR}$ :

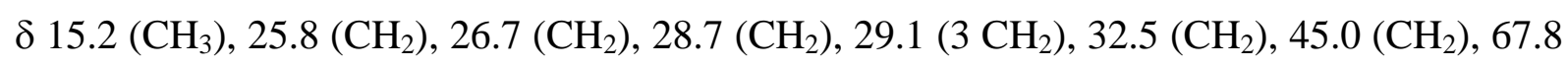
$\left(\mathrm{CH}_{2}\right), 82.6\left(2 \mathrm{CH}, \mathrm{C}_{5} \mathrm{H}_{4}\right), 85.5\left(2 \mathrm{CH}, \mathrm{C}_{5} \mathrm{H}_{4}\right), 109.1\left(1 \mathrm{C}, \mathrm{C}_{5} \mathrm{H}_{4}\right), 114.1(2 \mathrm{CH}), 115.3(2 \mathrm{CH})$, $129.9(2 \mathrm{CH}), 130.2(\mathrm{C}), 130.7(2 \mathrm{CH}), 135.2(\mathrm{C}), 136.0(\mathrm{C}), 142.0(\mathrm{C}), 154.4(\mathrm{C}), 158.0(\mathrm{C})$, 194.6 (3 CO). Minor isomer: ${ }^{1} \mathrm{H}$ NMR: $\delta 1.07$ (t, J = 7.5 Hz, 3H, $\left.\mathrm{CH}_{3}\right), 1.23-1.90(\mathrm{~m}, 12 \mathrm{H}$, $\left.\left(\mathrm{CH}_{2}\right)_{6^{-}}\right), 2.27\left(\mathrm{q}, \mathrm{J}=7.5 \mathrm{~Hz}, 2 \mathrm{H}, \mathrm{CH}_{2}\right), 3.55\left(\mathrm{t}, \mathrm{J}=6.6 \mathrm{~Hz}, 2 \mathrm{H}, \mathrm{CH}_{2}\right), 3.93(\mathrm{t}, \mathrm{J}=6.4 \mathrm{~Hz}, 2 \mathrm{H}$, $\left.\mathrm{CH}_{2}\right)$, 5.01-5.16 (m, 4H, $\left.\mathrm{C}_{5} \mathrm{H}_{4}\right), 6.68-6.90\left(\mathrm{~m}, 4 \mathrm{H}, \mathrm{H}_{\text {arom }}\right), 6.90-7.13\left(\mathrm{~m}, 4 \mathrm{H}, \mathrm{H}_{\text {arom }}\right) .{ }^{13} \mathrm{C} \mathrm{NMR}$ : ठ $15.2\left(\mathrm{CH}_{3}\right), 25.8\left(\mathrm{CH}_{2}\right), 26.7\left(\mathrm{CH}_{2}\right), 28.7\left(\mathrm{CH}_{2}\right), 29.1\left(3 \mathrm{CH}_{2}\right), 32.5\left(\mathrm{CH}_{2}\right), 45.0\left(\mathrm{CH}_{2}\right), 67.8$ $\left(\mathrm{CH}_{2}\right), 82.6\left(2 \mathrm{CH}, \mathrm{C}_{5} \mathrm{H}_{4}\right), 85.5\left(2 \mathrm{CH}, \mathrm{C}_{5} \mathrm{H}_{4}\right), 109.1\left(1 \mathrm{C}, \mathrm{C}_{5} \mathrm{H}_{4}\right), 114.4(2 \mathrm{CH}), 115.1(2 \mathrm{CH})$, 
$130.1(2 \mathrm{CH}), 130.2(\mathrm{C}), 130.5$ (2 CH), $135.5(\mathrm{C}), 135.7(\mathrm{C}), 142.0(\mathrm{C}), 154.3(\mathrm{C}), 157.9(\mathrm{C})$, 194.6 (3 CO).

Amines 7a-e : Halide 6a-e (3 mmol) was added into a solution of dimethylamine in methanol (2M, $15 \mathrm{ml}, 30 \mathrm{mmol}$ ) placed in an autoclave. The mixture was heated with stirring at $60^{\circ} \mathrm{C}$ for 1 day (6a-d) or 3 days (6e). After cooling, the solution was concentrated under reduced pressure. The residue was chromatographed on silica gel plates (chloroform:triethylamine 80:20 as eluent). After solvent evaporation, the residue obtained was dissolved in dichloromethane and the solution was washed three times with water. The organic layer was dried over magnesium sulfate then the solution was concentrated under reduced pressure to furnish pure amines 7a-e as oils containing a mixture of $Z$ and $E$ isomers. The $Z$ and $E$ isomers were separated on reverse phase semi-preparative Kromasil C18 column (diameter 2 $\mathrm{cm}$, length $25 \mathrm{~cm})$, eluent methanol:phosphate buffer $\left(\mathrm{KH}_{2} \mathrm{PO}_{4}, 25 \mathrm{mM}, \mathrm{pH}\right.$ 7) ratio : 82:18 for $\mathbf{7 a}, 83: 17$ for $\mathbf{7 b}, 87: 13$ for $\mathbf{7 c}, 88: 12$ for $\mathbf{7 d}, 92: 8$ for $\mathbf{7 e}$, flow rate $6 \mathrm{~mL} / \mathrm{min}$.

7a Yield 82\%. Major isomer $(E)$ : $\mathrm{mp} 141^{\circ} \mathrm{C}$. IR: $3449(\mathrm{OH}), 2016$ and $1913(\mathrm{C}=\mathrm{O}) \mathrm{cm}^{-1} ;{ }^{1} \mathrm{H}$ NMR: $\delta 1.04\left(\mathrm{t}, \mathrm{J}=7.4 \mathrm{~Hz}, 3 \mathrm{H}, \mathrm{CH}_{3}\right), 2.29\left(\mathrm{q}, \mathrm{J}=7.4 \mathrm{~Hz}, 2 \mathrm{H}, \mathrm{CH}_{2}\right.$ ), $2.43\left(\mathrm{~s}, 6 \mathrm{H}, \mathrm{NMe}_{2}\right.$ ), 2.83 $\left(\mathrm{t}, \mathrm{J}=5.3 \mathrm{~Hz}, 2 \mathrm{H}, \mathrm{NCH}_{2}\right), 4.04\left(\mathrm{t}, \mathrm{J}=5.3 \mathrm{~Hz}, 2 \mathrm{H}, \mathrm{OCH}_{2}\right), 5.11\left(\mathrm{~s}, 4 \mathrm{H}, \mathrm{C}_{5} \mathrm{H}_{4}\right), 6.48(\mathrm{~d}, \mathrm{~J}=8.7$ $\left.\mathrm{Hz}, 2 \mathrm{H}, \mathrm{H}_{\text {arom }}\right), 6.71$ (d, J = 8.6 Hz, 2H, $\left.\mathrm{H}_{\text {arom }}\right), 6.91$ (d, J = 8.6 Hz, 2H, $\mathrm{H}_{\text {arom }}$ ), 6.97 (d, J = 8.7 $\left.\mathrm{Hz}, 2 \mathrm{H}, \mathrm{H}_{\text {arom }}\right) ;{ }^{13} \mathrm{C}$ NMR: $\delta 15.3\left(\mathrm{CH}_{3}\right), 29.1\left(\mathrm{CH}_{2}\right), 45.0\left(2 \mathrm{CH}_{3}\right), 58.0\left(\mathrm{CH}_{2}\right), 64.1\left(\mathrm{CH}_{2}\right)$, $82.6\left(2 \mathrm{CH}, \mathrm{C}_{5} \mathrm{H}_{4}\right), 85.4\left(2 \mathrm{CH}, \mathrm{C}_{5} \mathrm{H}_{4}\right), 109.8\left(1 \mathrm{C}, \mathrm{C}_{5} \mathrm{H}_{4}\right), 113.7(2 \mathrm{CH}), 115.9(2 \mathrm{CH}), 129.5$ (C), 130.0 (2 CH), 130.8 (2 CH), 134.6 (C), 135.7 (C), 142.4 (C), 156.2 (C), 157.3 (C), 194.7 (3 CO). MS (IE, $70 \mathrm{eV}$ ) m/z: $645[\mathrm{M}]^{+}$, $561[\mathrm{M}-3 \mathrm{CO}]^{+}$. Anal. Calcd for $\mathrm{C}_{28} \mathrm{H}_{28} \mathrm{NO}_{5} \mathrm{Re}: \mathrm{C}$, 52.16; H, 4.38; N, 2.17. Found: C, 51.53; H, 4.51; N, 2.16. Minor isomer (Z): mp $110^{\circ} \mathrm{C}$. IR: $3438(\mathrm{OH}), 2016$ and $1913(\mathrm{C}=\mathrm{O}) \mathrm{cm}^{-1} .{ }^{1} \mathrm{H}$ NMR: $\delta 1.07\left(\mathrm{t}, \mathrm{J}=7.4 \mathrm{~Hz}, 3 \mathrm{H}, \mathrm{CH}_{3}\right), 2.31(\mathrm{q}, \mathrm{J}=$ $\left.7.4 \mathrm{~Hz}, 2 \mathrm{H}, \mathrm{CH}_{2}\right), 2.42\left(\mathrm{~s}, 6 \mathrm{H}, \mathrm{NMe}_{2}\right), 2.82\left(\mathrm{t}, \mathrm{J}=5.3 \mathrm{~Hz}, 2 \mathrm{H}, \mathrm{NCH}_{2}\right), 4.04(\mathrm{t}, \mathrm{J}=5.3 \mathrm{~Hz}, 2 \mathrm{H}$, $\left.\mathrm{OCH}_{2}\right), 5.00-5.20\left(\mathrm{~m}, 4 \mathrm{H}, \mathrm{C}_{5} \mathrm{H}_{4}\right), 6.55\left(\mathrm{~d}, \mathrm{~J}=8.7 \mathrm{~Hz}, 2 \mathrm{H}, \mathrm{H}_{\text {arom }}\right), 6.77(\mathrm{~d}, \mathrm{~J}=8.7 \mathrm{~Hz}, 2 \mathrm{H}$, $\left.\mathrm{H}_{\text {arom }}\right), 6.93\left(\mathrm{~d}, \mathrm{~J}=8.7 \mathrm{~Hz}, 2 \mathrm{H}, \mathrm{H}_{\text {arom }}\right), 7.00\left(\mathrm{~d}, \mathrm{~J}=8.7 \mathrm{~Hz}, 2 \mathrm{H}, \mathrm{H}_{\text {arom }}\right) .{ }^{13} \mathrm{C} \mathrm{NMR}: \delta 15.2$ $\left(\mathrm{CH}_{3}\right), 29.0\left(\mathrm{CH}_{2}\right), 45.1\left(2 \mathrm{CH}_{3}\right), 58.0\left(\mathrm{CH}_{2}\right), 64.3\left(\mathrm{CH}_{2}\right), 82.5\left(2 \mathrm{CH}, \mathrm{C}_{5} \mathrm{H}_{4}\right), 85.5(2 \mathrm{CH}$, $\left.\mathrm{C}_{5} \mathrm{H}_{4}\right), 109.9$ (1 C, $\left.\mathrm{C}_{5} \mathrm{H}_{4}\right), 114.0(2 \mathrm{CH}), 115.6(2 \mathrm{CH}), 129.7(\mathrm{C}), 130.2(2 \mathrm{CH}), 130.6$ (2 CH), 134.2 (C), 136.1 (C), 142.5 (C), 156.0 (C), 157.4 (C), 194.6 (3 CO); MS (IE, 70 eV) m/z: $645[\mathrm{M}]^{+}$. Anal. Calcd for $\mathrm{C}_{28} \mathrm{H}_{28} \mathrm{NO}_{5} \mathrm{Re}$ : C, 52.16; H, 4.38; N, 2.17. Found: C, 52.04; $\mathrm{H}, 4.55 ; \mathrm{N}, 2.29$. 


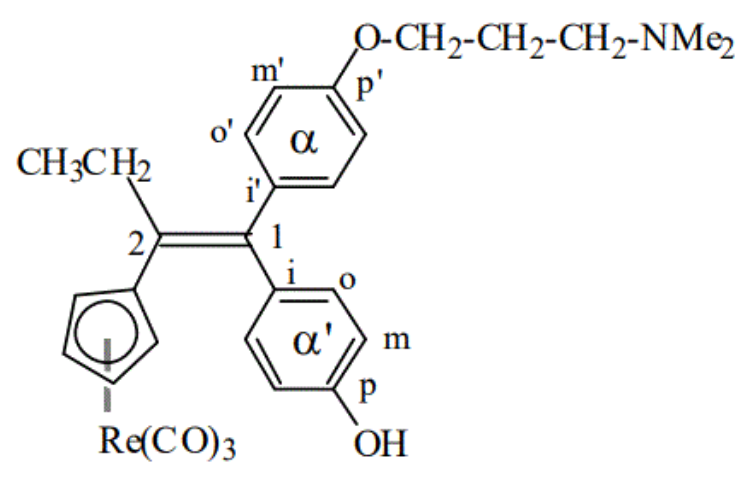

$7 \mathbf{b}(E)$

7b : Yield 64\%. Major isomer $(E)$ : mp $161^{\circ} \mathrm{C}$. IR: $3431(\mathrm{OH}), 2018$ and $1930(\mathrm{C}=\mathrm{O}) \mathrm{cm}^{-1} .{ }^{1} \mathrm{H}$ NMR (400 MHz): $\delta 1.04$ (t, J = 7.4 Hz, 3H, CH $), 1.97$ (qint., 2H, $\mathrm{CH}_{2} \mathrm{CH}_{2} \mathrm{CH}_{2}$ ), 2.24 (q, J = $\left.7.5 \mathrm{~Hz}, 2 \mathrm{H}, \mathrm{CH}_{2} \mathrm{CH}_{3}\right), 2.31\left(\mathrm{~s}, 6 \mathrm{H}, \mathrm{NMe}_{2}\right), 2.55\left(\mathrm{t}, \mathrm{J}=7.3 \mathrm{~Hz}, 2 \mathrm{H}, \mathrm{NCH}_{2}\right), 3.94(\mathrm{t}, \mathrm{J}=6.2 \mathrm{~Hz}$, $\left.2 \mathrm{H}, \mathrm{OCH}_{2}\right), 5.07\left(\mathrm{~m}, 4 \mathrm{H}, \mathrm{C}_{5} \mathrm{H}_{4}\right), 6.67\left(\mathrm{~d}, \mathrm{~J}=8.4 \mathrm{~Hz}, 2 \mathrm{H}, \mathrm{H}_{\alpha^{\prime} \mathrm{m}}\right), 6.76\left(\mathrm{~d}, \mathrm{~J}=8.6 \mathrm{~Hz}, 2 \mathrm{H}, \mathrm{H}_{\alpha \mathrm{m}}\right)$, $6.92\left(\mathrm{~d}, \mathrm{~J}=8.4 \mathrm{~Hz}, 2 \mathrm{H}, \mathrm{H}_{\alpha^{\prime} \mathrm{o}}\right), 7.02\left(\mathrm{~d}, \mathrm{~J}=8.6 \mathrm{~Hz}, 2 \mathrm{H}, \mathrm{H}_{\alpha \mathrm{o}}\right) .{ }^{13} \mathrm{C} \mathrm{NMR}: \delta 15.4\left(\mathrm{CH}_{3}\right), 27.0$ $\left(\mathrm{CH}_{2} \mathrm{CH}_{2} \mathrm{CH}_{2}\right), 29.1\left(\mathrm{CH}_{2} \mathrm{CH}_{3}\right), 45.1\left(\mathrm{NMe}_{2}\right), 56.3\left(\mathrm{CH}_{2} \mathrm{~N}\right), 66.0\left(\mathrm{OCH}_{2}\right), 82.8$ and $85.7(4 \mathrm{C}$, $\mathrm{C}_{2^{\prime}}$ and $\left.\mathrm{C}_{3^{\prime}}, \mathrm{C}_{5} \mathrm{H}_{4}\right), 109.4\left(\mathrm{C}_{1^{\prime}}, \mathrm{C}_{5} \mathrm{H}_{4}\right), 114.2\left(2 \mathrm{C}_{\alpha \mathrm{m}}\right), 115.8\left(2 \mathrm{C}_{\alpha^{\prime} \mathrm{m}}\right), 130.1\left(\mathrm{C}_{2}\right), 130.1\left(\mathrm{C}_{\alpha \mathrm{o}}\right)$, $130.8\left(\mathrm{C}_{\alpha^{\prime} \mathrm{o}}\right), 135.1\left(\mathrm{C}_{\alpha^{\prime} \mathrm{ip}}\right), 135.8\left(\mathrm{C}_{\alpha \mathrm{ip}}\right), 142.5\left(\mathrm{C}_{1}\right), 155.9\left(\mathrm{C}_{\alpha \mathrm{p}}\right), 157.8\left(\mathrm{C}_{\alpha^{\prime} \mathrm{o}}\right), 194.9(3 \mathrm{CO})$. MS (IE, $70 \mathrm{eV}$ ) m/z: 659 [M] $]^{+}$. Anal. Calcd for $\mathrm{C}_{29} \mathrm{H}_{30} \mathrm{NO}_{5} \mathrm{Re}: \mathrm{C}, 52.88 ; \mathrm{H}, 4.59 ; \mathrm{N}, 2.13$. Found: C, 52.67; H, 4.78; N, 2.14. Minor isomer (Z): mp: $162^{\circ} \mathrm{C}$; IR (KBr): $3432(\mathrm{OH}), 2015$ and $1899(\mathrm{C}=\mathrm{O}) \mathrm{cm}^{-1}$; ${ }^{1} \mathrm{H}$ NMR: $\delta 1.08\left(\mathrm{t}, \mathrm{J}=7.4 \mathrm{~Hz}, 3 \mathrm{H}, \mathrm{CH}_{3}\right), 1.80-2.10\left(\mathrm{~m}, 2 \mathrm{H}, \mathrm{CH}_{2}\right), 2.30$ (q, J = 7.4 Hz, 2H, $\left.\mathrm{CH}_{2}\right), 2.35\left(\mathrm{~s}, 6 \mathrm{H}, \mathrm{NMe}_{2}\right), 2.59$ (t, J = $\left.7.5 \mathrm{~Hz}, 2 \mathrm{H}, \mathrm{NCH}_{2}\right), 3.97$ (t, J = 6.1 $\left.\mathrm{Hz}, 2 \mathrm{H}, \mathrm{OCH}_{2}\right), 5.06$ and $5.11\left(\mathrm{~m}, \mathrm{~m}, 4 \mathrm{H}, \mathrm{C}_{5} \mathrm{H}_{4}\right), 6.73\left(\mathrm{~d}, \mathrm{~J}=8.5 \mathrm{~Hz}, 2 \mathrm{H}, \mathrm{H}_{\text {arom }}\right), 6.75(\mathrm{~d}, \mathrm{~J}=$ $\left.8.5 \mathrm{~Hz}, 2 \mathrm{H}, \mathrm{H}_{\text {arom }}\right), 7.00\left(\mathrm{~d}, \mathrm{~J}=8.5 \mathrm{~Hz}, 2 \mathrm{H}, \mathrm{H}_{\text {arom }}\right), 7.01\left(\mathrm{~d}, \mathrm{~J}=8.5 \mathrm{~Hz}, 2 \mathrm{H}, \mathrm{H}_{\text {arom }}\right) .{ }^{13} \mathrm{C} \mathrm{NMR}$ : $\delta 15.2\left(\mathrm{CH}_{3}\right), 26.5\left(\mathrm{CH}_{2}\right), 28.9\left(\mathrm{CH}_{2}\right), 44.6\left(2 \mathrm{CH}_{3}\right), 56.1\left(\mathrm{CH}_{2}\right), 65.7\left(\mathrm{CH}_{2}\right), 82.6(2 \mathrm{CH}$, $\left.\mathrm{C}_{5} \mathrm{H}_{4}\right), 85.5\left(2 \mathrm{CH}, \mathrm{C}_{5} \mathrm{H}_{4}\right), 109.2\left(1 \mathrm{C}, \mathrm{C}_{5} \mathrm{H}_{4}\right), 114.1(2 \mathrm{CH}), 115.7(2 \mathrm{CH}), 129.9(\mathrm{C}), 130.0$ (2 CH), 130.6 (2 CH), 134.7 (C), 135.7 (C), 142.3 (C), 155.9 (C), 157.5 (C), 194.7 (3 CO). MS (IE, $70 \mathrm{eV}$ ) m/z: $659[\mathrm{M}]^{+.}$. Anal. Calcd for $\mathrm{C}_{29} \mathrm{H}_{30} \mathrm{NO}_{5} \mathrm{Re}: \mathrm{C}, 52.88 ; \mathrm{H}, 4.59 ; \mathrm{N}, 2.13$. Found: C, 52.72; H, 4.79; N, 2.05 . 


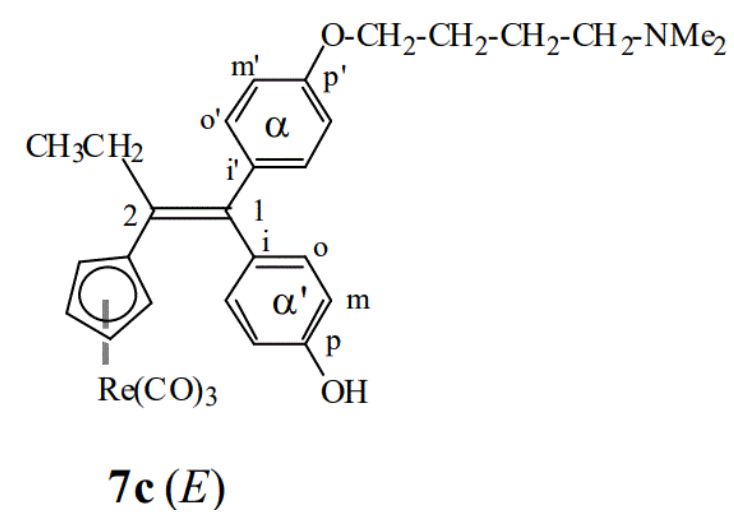

7c : Yield 64\%. Major isomer $(E)$ : $\mathrm{mp} 153^{\circ} \mathrm{C}$. IR $(\mathrm{KBr}): 3448(\mathrm{OH}), 2018$ and $1918(\mathrm{C}=\mathrm{O})$ $\mathrm{cm}^{-1}$; Yield 64\%. ${ }^{1} \mathrm{H}$ NMR (400 MHz): $\delta 1.05\left(\mathrm{t}, \mathrm{J}=7.3 \mathrm{~Hz}, 3 \mathrm{H}, \mathrm{CH}_{3}\right), 1.69(\mathrm{~m}, 2 \mathrm{H}$, $\mathrm{CH}_{2} \mathrm{CH}_{2} \mathrm{CH}_{2} \mathrm{CH}_{2}$ ), 1.76 (m, 2H, $\mathrm{CH}_{2} \mathrm{CH}_{2} \mathrm{CH}_{2} \mathrm{CH}_{2}$ ), 2.25 (q, J = 7.5 Hz, $\left.2 \mathrm{H}, \mathrm{CH}_{2}\right), 2.32(\mathrm{~s}, 6 \mathrm{H}$, $\mathrm{NMe}_{2}$ ), $2.44\left(\mathrm{t}, \mathrm{J}=6.6 \mathrm{~Hz}, 2 \mathrm{H}, \mathrm{NCH}_{2}\right), 3.91\left(\mathrm{t}, \mathrm{J}=5.5 \mathrm{~Hz}, 2 \mathrm{H}, \mathrm{OCH}_{2}\right), 5.06$ and 5.10 (s, s, $\left.2 \mathrm{H}, 2 \mathrm{H}, \mathrm{C}_{5} \mathrm{H}_{4}\right), 6.70\left(\mathrm{~d}, \mathrm{~J}=8.0 \mathrm{~Hz}, 2 \mathrm{H}, \mathrm{H}_{\alpha^{\prime} \mathrm{m}}\right), 6.78\left(\mathrm{~d}, \mathrm{~J}=8.2 \mathrm{~Hz}, 2 \mathrm{H}, \mathrm{H}_{a \mathrm{~m}}\right), 6.93(\mathrm{~d}, \mathrm{~J}=8.0$ $\left.\mathrm{Hz}, 2 \mathrm{H}, \mathrm{H}_{\alpha^{\prime} \mathrm{o}}\right), 7.03\left(\mathrm{~d}, \mathrm{~J}=8.2 \mathrm{~Hz}, 2 \mathrm{H}, \mathrm{H}_{\alpha 0}\right) \cdot{ }^{13} \mathrm{C}$ NMR: $\delta 15.4\left(\mathrm{CH}_{3}\right), 23.9$ $\left(\mathrm{OCH}_{2} \mathrm{CH}_{2} \mathrm{CH}_{2} \mathrm{CH}_{2}\right), 27.2\left(\mathrm{OCH}_{2} \mathrm{CH}_{2} \mathrm{CH}_{2} \mathrm{CH}_{2}\right), 29.1\left(\mathrm{CH}_{2} \mathrm{CH}_{3}\right), 45.0\left(\mathrm{NMe}_{2}\right), 59.2\left(\mathrm{CH}_{2} \mathrm{~N}\right)$, $67.5\left(\mathrm{OCH}_{2}\right), 82.8$ and $85.7\left(4 \mathrm{C}, \mathrm{C}_{2^{\prime}}\right.$ and $\left.\mathrm{C}_{3^{\prime}}, \mathrm{C}_{5} \mathrm{H}_{4}\right), 109.4\left(\mathrm{C}_{1}, \mathrm{C}_{5} \mathrm{H}_{4}\right), 114.3\left(2 \mathrm{C}_{\alpha \mathrm{m}}\right), 115.7(2$ $\left.\mathrm{C}_{\alpha^{\prime} \mathrm{m}}\right), 130.1\left(\mathrm{C}_{\alpha \mathrm{o} 0}\right), 130.2\left(\mathrm{C}_{2}\right), 130.8\left(\mathrm{C}_{\alpha^{\prime} \mathrm{o}}\right), 135.5\left(\mathrm{C}_{\alpha \mathrm{pip}}\right), 135.7\left(\mathrm{C}_{\alpha^{\prime} \mathrm{p}}\right), 142.4\left(\mathrm{C}_{1}\right), 155.1\left(\mathrm{C}_{\alpha^{\prime} \mathrm{p}}\right)$, $157.9\left(\mathrm{C}_{\text {ap }}\right), 194.9$ (3 CO). MS (IE, $\left.70 \mathrm{eV}\right) \mathrm{m} / \mathrm{z}: 673[\mathrm{M}]^{+}$. Minor isomer $(Z): \mathrm{mp} 134^{\circ} \mathrm{C}$. IR: $3437(\mathrm{OH}), 2018$ and $1902(\mathrm{C}=\mathrm{O}) \mathrm{cm}^{-1} .{ }^{1} \mathrm{H}$ NMR: $\delta 1.06\left(\mathrm{t}, \mathrm{J}=7.4 \mathrm{~Hz}, 3 \mathrm{H}, \mathrm{CH}_{3}\right), 1.56-1.87$ (m, 4H, 2 $\mathrm{CH}_{2}$ ), 2.27 (q, J = 7.4 Hz, 2H, $\mathrm{CH}_{2}$ ), $2.31\left(\mathrm{~s}, 6 \mathrm{H}, \mathrm{NMe}_{2}\right), 2.42(\mathrm{t}, \mathrm{J}=7.1 \mathrm{~Hz}, 2 \mathrm{H}$, $\left.\mathrm{NCH}_{2}\right), 3.91\left(\mathrm{t}, \mathrm{J}=5.7 \mathrm{~Hz}, 2 \mathrm{H}, \mathrm{OCH}_{2}\right), 5.07-5.12\left(\mathrm{~m}, \mathrm{~m}, 4 \mathrm{H}, \mathrm{C}_{5} \mathrm{H}_{4}\right), 6.74(\mathrm{~d}, \mathrm{~J}=8.4 \mathrm{~Hz}, 2 \mathrm{H}$, $\left.\mathrm{H}_{\text {arom }}\right), 6.75\left(\mathrm{~d}, \mathrm{~J}=8.4 \mathrm{~Hz}, 2 \mathrm{H}, \mathrm{H}_{\text {arom }}\right), 6.99\left(\mathrm{~d}, \mathrm{~J}=8.4 \mathrm{~Hz}, 2 \mathrm{H}, \mathrm{H}_{\text {arom }}\right), 7.00(\mathrm{~d}, \mathrm{~J}=8.4 \mathrm{~Hz}, 2 \mathrm{H}$, $\left.\mathrm{H}_{\text {arom }}\right){ }^{13} \mathrm{C}$ NMR: $\delta 15.2\left(\mathrm{CH}_{3}\right), 23.6\left(\mathrm{CH}_{2}\right), 27.0\left(\mathrm{CH}_{2}\right), 28.9\left(\mathrm{CH}_{2}\right), 44.8\left(2 \mathrm{CH}_{3}\right), 59.1$ $\left(\mathrm{CH}_{2}\right), 67.3\left(\mathrm{CH}_{2}\right), 82.6\left(2 \mathrm{CH}, \mathrm{C}_{5} \mathrm{H}_{4}\right), 85.5\left(2 \mathrm{CH}, \mathrm{C}_{5} \mathrm{H}_{4}\right), 109.3\left(1 \mathrm{C}, \mathrm{C}_{5} \mathrm{H}_{4}\right), 114.3(2 \mathrm{CH})$, $115.3(2 \mathrm{CH}), 129.9(2 \mathrm{CH}+\mathrm{C}), 130.5(2 \mathrm{CH}), 134.8(\mathrm{C}), 135.9(\mathrm{C}), 142.3(\mathrm{C}), 155.8(\mathrm{C})$, 157.7 (C), 194.7 (3 CO). MS (IE, $70 \mathrm{eV}$ ) m/z: $673[\mathrm{M}]^{+}$. Anal. Calcd for $\mathrm{C}_{30} \mathrm{H}_{32} \mathrm{NO}_{5} \mathrm{Re} . \mathrm{H}_{2} \mathrm{O}$ : C, 52.15; H, 4.96; N, 2.02. Found: C, 52.41; H, 5.09; N, 2.17.

7d : Yield 62\%. Major isomer (E): mp $140{ }^{\circ} \mathrm{C}$. IR: $3438(\mathrm{OH}), 2017$ and $1924(\mathrm{C}=\mathrm{O}) \mathrm{cm}^{-1} .{ }^{1} \mathrm{H}$ NMR: $\delta 1.05$ (t, J $\left.=7.5 \mathrm{~Hz}, 3 \mathrm{H}, \mathrm{CH}_{3}\right), 1.50$ and $1.76\left(\mathrm{~m}, \mathrm{~m}, 2 \mathrm{H}, 4 \mathrm{H}, 3 \mathrm{CH}_{2}\right), 2.28(\mathrm{q}, \mathrm{J}=7.5$ $\left.\mathrm{Hz}, 2 \mathrm{H}, \mathrm{CH}_{2}\right), 2.30\left(\mathrm{~s}, 6 \mathrm{H}, \mathrm{NMe}_{2}\right), 2.37\left(\mathrm{t}, \mathrm{J}=7.5 \mathrm{~Hz}, 2 \mathrm{H}, \mathrm{NCH}_{2}\right), 3.88(\mathrm{t}, \mathrm{J}=6.4 \mathrm{~Hz}, 2 \mathrm{H}$, $\left.\mathrm{OCH}_{2}\right), 5.02-5.10\left(\mathrm{~m}, 4 \mathrm{H}, \mathrm{C}_{5} \mathrm{H}_{4}\right), 6.67\left(\mathrm{~d}, \mathrm{~J}=8.6 \mathrm{~Hz}, 2 \mathrm{H}, \mathrm{H}_{\text {arom }}\right), 6.78(\mathrm{~d}, \mathrm{~J}=8.6 \mathrm{~Hz}, 2 \mathrm{H}$, $\left.\mathrm{H}_{\text {arom }}\right), 6.93\left(\mathrm{~d}, \mathrm{~J}=8.6 \mathrm{~Hz}, 2 \mathrm{H}, \mathrm{H}_{\text {arom }}\right), 7.04\left(\mathrm{~d}, \mathrm{~J}=8.6 \mathrm{~Hz}, 2 \mathrm{H}, \mathrm{H}_{\text {arom }}\right) .{ }^{13} \mathrm{C}$ NMR: $\delta 15.2$ $\left(\mathrm{CH}_{3}\right), 23.8\left(\mathrm{CH}_{2}\right), 26.1\left(\mathrm{CH}_{2}\right), 26.2\left(\mathrm{CH}_{2}\right), 28.9\left(\mathrm{CH}_{2}\right), 44.6\left(2 \mathrm{CH}_{3}\right), 59.1\left(\mathrm{CH}_{2}\right), 67.4\left(\mathrm{CH}_{2}\right)$, 
$82.6\left(2 \mathrm{CH}, \mathrm{C}_{5} \mathrm{H}_{4}\right), 85.5\left(2 \mathrm{CH}, \mathrm{C}_{5} \mathrm{H}_{4}\right), 109.5\left(1 \mathrm{C}, \mathrm{C}_{5} \mathrm{H}_{4}\right), 114.0(2 \mathrm{CH}), 115.8(2 \mathrm{CH}), 129.6$ (C), 129.8 (2 CH), 130.5 (2 CH), 134.2 (C), 135.6 (C), 142.6 (C), 156.5 (C), 157.7 (C), 194.7 (3 CO); MS (IE, $70 \mathrm{eV}$ ) m/z: $687[\mathrm{M}]^{+}, 603[\mathrm{M}-3 \mathrm{CO}]^{+}$. Anal. Calcd for $\mathrm{C}_{31} \mathrm{H}_{34} \mathrm{NO}_{5} \mathrm{Re}: \mathrm{C}$, 54.21; H, 4.99; N, 2.04. Found: C, 54.31; H, 5.11; N, 2.00. Minor isomer (Z): mp: $120{ }^{\circ} \mathrm{C}$. IR: $3436(\mathrm{OH}), 2018$ and $1918(\mathrm{C}=\mathrm{O}) \mathrm{cm}^{-1}$. ${ }^{1} \mathrm{H}$ NMR: $\delta 1.06\left(\mathrm{t}, \mathrm{J}=7.4 \mathrm{~Hz}, 3 \mathrm{H}, \mathrm{CH}_{3}\right), 1.34-1.86$ $\left(\mathrm{m}, 6 \mathrm{H}, 3 \mathrm{CH}_{2}\right), 2.28$ (q, J = 7.4 Hz, 2H, $\left.\mathrm{CH}_{2}\right), 2.31$ (s, 6H, $\left.\mathrm{NMe}_{2}\right), 2.39$ (t, J = $7.4 \mathrm{~Hz}, 2 \mathrm{H}$, $\left.\mathrm{NCH}_{2}\right), 3.87\left(\mathrm{t}, \mathrm{J}=6.3 \mathrm{~Hz}, 2 \mathrm{H}, \mathrm{OCH}_{2}\right), 5.07$ and $5.14\left(\mathrm{~m}, \mathrm{~m}, 4 \mathrm{H}, \mathrm{C}_{5} \mathrm{H}_{4}\right), 6.70(\mathrm{~d}, \mathrm{~J}=8.4 \mathrm{~Hz}$, $\left.2 \mathrm{H}, \mathrm{H}_{\text {arom }}\right), 6.74\left(\mathrm{~d}, \mathrm{~J}=8.4 \mathrm{~Hz}, 2 \mathrm{H}, \mathrm{H}_{\text {arom }}\right), 6.98\left(\mathrm{~d}, \mathrm{~J}=8.4 \mathrm{~Hz}, 4 \mathrm{H}, \mathrm{H}_{\text {arom }}\right) .{ }^{13} \mathrm{C} \mathrm{NMR}: \delta 15.2$ $\left(\mathrm{CH}_{3}\right), 23.8\left(\mathrm{CH}_{2}\right), 26.1\left(\mathrm{CH}_{2}\right), 26.2\left(\mathrm{CH}_{2}\right), 28.9\left(\mathrm{CH}_{2}\right), 44.6\left(2 \mathrm{CH}_{3}\right), 59.1\left(\mathrm{CH}_{2}\right), 67.4\left(\mathrm{CH}_{2}\right)$, $82.6\left(2 \mathrm{CH}, \mathrm{C}_{5} \mathrm{H}_{4}\right), 85.5\left(2 \mathrm{CH}, \mathrm{C}_{5} \mathrm{H}_{4}\right), 109.3\left(1 \mathrm{C}, \mathrm{C}_{5} \mathrm{H}_{4}\right), 114.3(2 \mathrm{CH}), 115.5(2 \mathrm{CH}), 129.7$ (C), 129.9 (2 CH), 130.5 (2 CH), 134.0 (C), 135.9 (C), 142.5 (C), 156.3 (C), 157.8 (C), 194.7 (3 CO). MS (IE, $70 \mathrm{eV}$ ) m/z: $687[\mathrm{M}]^{+}$, $603[\mathrm{M}-3 \mathrm{CO}]^{+}$. Anal. Calcd for $\mathrm{C}_{31} \mathrm{H}_{34} \mathrm{NO}_{5} \mathrm{Re} \cdot \mathrm{H}_{2} \mathrm{O}$ : C, 52.82; H, 5.15; N, 2.00. Found: C, 53.29; H, 5.43; N, 1.98.

7e : Yield 63\%. Major isomer (E): mp: $88^{\circ} \mathrm{C}$. IR: $3428(\mathrm{OH}), 2018$ and $1920(\mathrm{C}=\mathrm{O}) \mathrm{cm}^{-1}$. ${ }^{1} \mathrm{H}$ NMR: $\delta 1.05\left(\mathrm{t}, \mathrm{J}=7.4 \mathrm{~Hz}, 3 \mathrm{H}, \mathrm{CH}_{3}\right), 1.17-1.84\left(\mathrm{~m}, 12 \mathrm{H}, 6 \mathrm{CH}_{2}\right), 2.15-2.45(\mathrm{~m}, 10 \mathrm{H}$, $\left.\mathrm{CH}_{2}+\mathrm{NMe}_{2}+\mathrm{NCH}_{2}\right), 3.91\left(\mathrm{t}, \mathrm{J}=6.4 \mathrm{~Hz}, 2 \mathrm{H}, \mathrm{OCH}_{2}\right), 5.09\left(\mathrm{~s}, 4 \mathrm{H}, \mathrm{C}_{5} \mathrm{H}_{4}\right), 6.67(\mathrm{~d}, \mathrm{~J}=7.9 \mathrm{~Hz}$, 2H, $\mathrm{H}_{\text {arom }}$ ), 6.82 (d, J = 8.6 Hz, 2H, $\left.\mathrm{H}_{\text {arom }}\right), 6.93$ (d, J = 7.9 Hz, 2H, $\left.\mathrm{H}_{\text {arom }}\right), 7.05$ (d, J = 8.6 Hz, $\left.2 \mathrm{H}, \mathrm{H}_{\text {arom }}\right) .{ }^{13} \mathrm{C}$ NMR: $\delta 15.2\left(\mathrm{CH}_{3}\right), 25.8\left(2 \mathrm{CH}_{2}\right), 26.9\left(\mathrm{CH}_{2}\right), 28.8\left(\mathrm{CH}_{2}\right), 29.0\left(\mathrm{CH}_{2}\right), 29.1$ $\left(\mathrm{CH}_{2}\right), 29.2\left(\mathrm{CH}_{2}\right), 44.1\left(2 \mathrm{CH}_{3}\right), 58.8\left(\mathrm{CH}_{2}\right), 67.7\left(\mathrm{CH}_{2}\right), 82.6\left(2 \mathrm{CH}, \mathrm{C}_{5} \mathrm{H}_{4}\right), 85.4(2 \mathrm{CH}$, $\left.\mathrm{C}_{5} \mathrm{H}_{4}\right), 109.3\left(1 \mathrm{C}, \mathrm{C}_{5} \mathrm{H}_{4}\right), 114.0(2 \mathrm{CH}), 115.8(2 \mathrm{CH}), 129.5(\mathrm{C}), 129.8(2 \mathrm{CH}), 130.3$ (2 $\mathrm{CH}$ ), 134.0 (C), 135.6 (C), 142.6 (C), 156.7 (C), 157.7 (C), 194.7 (3 CO). MS (IE, 70 eV) m/z: $729[\mathrm{M}]^{+}, 645[\mathrm{M}-3 \mathrm{CO}]^{+}$. Anal. Calcd for $\mathrm{C}_{34} \mathrm{H}_{40} \mathrm{NO}_{5} \mathrm{Re}: \mathrm{C}, 56.03 ; \mathrm{H}, 5.53 ; \mathrm{N}, 1.92$. Found: C, 55.85; H, 5.71; N, 1.85. Minor isomer (Z): mp: $92{ }^{\circ} \mathrm{C}$. IR: $3428(\mathrm{OH}), 2018$ and $1918(\mathrm{C}=\mathrm{O}) \mathrm{cm}^{-1} .{ }^{1} \mathrm{H}$ NMR: $\delta 1.06\left(\mathrm{t}, \mathrm{J}=7.4 \mathrm{~Hz}, 3 \mathrm{H}, \mathrm{CH}_{3}\right), 1.17-1.84\left(\mathrm{~m}, 12 \mathrm{H}, 6 \mathrm{CH}_{2}\right), 2.15-$ $2.45\left(\mathrm{~m}, 10 \mathrm{H}, \mathrm{CH}_{2}+\mathrm{NMe}_{2}+\mathrm{NCH}_{2}\right), 3.90\left(\mathrm{t}, \mathrm{J}=6.4 \mathrm{~Hz}, 2 \mathrm{H}, \mathrm{OCH}_{2}\right), 5.08$ and $5.11(\mathrm{~m}, 4 \mathrm{H}$, $\left.\mathrm{C}_{5} \mathrm{H}_{4}\right), 6.72\left(\mathrm{~d}, \mathrm{~J}=8.8 \mathrm{~Hz}, 2 \mathrm{H}, \mathrm{H}_{\text {arom }}\right), 6.77$ (d, J = 8.8 Hz, 2H, $\left.\mathrm{H}_{\text {arom }}\right), 6.99$ (d, J = 8.8 Hz, 4H, $\left.\mathrm{H}_{\text {arom }}\right) .{ }^{13} \mathrm{C}$ NMR: $\delta 15.2\left(\mathrm{CH}_{3}\right), 25.8\left(2 \mathrm{CH}_{2}\right), 26.9\left(\mathrm{CH}_{2}\right), 28.8\left(\mathrm{CH}_{2}\right), 29.0\left(\mathrm{CH}_{2}\right), 29.1$ $\left(\mathrm{CH}_{2}\right), 29.2\left(\mathrm{CH}_{2}\right), 44.1\left(2 \mathrm{CH}_{3}\right), 58.8\left(\mathrm{CH}_{2}\right), 67.7\left(\mathrm{CH}_{2}\right), 82.6\left(2 \mathrm{CH}, \mathrm{C}_{5} \mathrm{H}_{4}\right), 85.4(2 \mathrm{CH}$, $\left.\mathrm{C}_{5} \mathrm{H}_{4}\right), 109.5\left(1 \mathrm{C}, \mathrm{C}_{5} \mathrm{H}_{4}\right), 114.3(2 \mathrm{CH}), 115.5(2 \mathrm{CH}), 129.5(\mathrm{C}), 129.8(2 \mathrm{CH}), 130.4$ (2 CH), 133.8 (C), 135.8 (C), 142.7 (C), 156.5 (C), 157.9 (C), 194.7 (3 CO). MS (IE, 70 eV) m/z: $729[\mathrm{M}]^{+}, 645[\mathrm{M}-3 \mathrm{CO}]^{+}$. Anal. Calcd for $\mathrm{C}_{34} \mathrm{H}_{40} \mathrm{NO}_{5} \mathrm{Re} . \mathrm{H}_{2} \mathrm{O}: \mathrm{C}, 54.67 ; \mathrm{H}, 5.66 ; \mathrm{N}$, 1.87. Found: C, 54.80; H, 5.88; N, 1.93. 
